\title{
Review
}

\section{Efficacy and Tolerability of Baclofen in Substance Use Disorders: A Systematic Review}

\author{
Roberta Agabio ${ }^{a}$ b Antonio Pretic, ${ }^{c}$ Gian Luigi Gessa ${ }^{a}$, e \\ ${ }^{a}$ Department of Biomedical Sciences, Section of Neuroscience, Clinical Pharmacology, ${ }^{b}$ Center of Excellence on \\ Neurobiology of Dependence, and ' Unit of Psychosomatics and Clinical Psychiatry, University Hospital, \\ University of Cagliari, d Genneruxi Medical Center, and eNeuroscience Institute, National Research Council of Italy, \\ Section of Cagliari, Cagliari, Italy
}

\section{Key Words}

Baclofen · Alcohol · Substance use disorders · Withdrawal

\begin{abstract}
Background: It has been reported that baclofen, a drug used in the treatment of spasticity, reduces the severity of withdrawal symptoms and substance use disorders (SUDs) for some psychoactive drugs. Aims and Methods: To evaluate the effectiveness and safety of baclofen in the treatment of withdrawal syndrome and/or SUDs, providing (1) an outline of its pharmacological features; (2) a summary of studies that have suggested its possible effectiveness in the treatment of SUDs, and (3) a review of randomized, controlled trials (RCTs) on baclofen and SUDs. Results: Baclofen tolerability is generally considered to be good. Eleven RCTs investigated its effectiveness in the treatment of SUDs. Of these, 5 RCTs found that baclofen is effective, 5 RCTs found that it is ineffective and the results of 1 RCT were not appreciable because it did not achieve the preplanned level of participation. Conclusions: The number of RCTs on baclofen and SUDs is still low, and their results are divergent. Further RCTs should be undertaken, particularly with higher doses of baclofen. Its administration may be suggested in patients who fail to respond to other approved drugs or who are affected by liver disease
\end{abstract}

that prevents their administration, or in patients affected by SUDs for which no approved drugs are available. Treatment should be conducted under strict medical supervision.

Copyright $\odot 2013$ S. Karger AG, Base

\section{Introduction}

The majority of subjects affected by substance use disorders (SUDs) do not receive pharmacological treatment [1]. There are several reasons for this, including the feeling reported by many patients of being strong enough to solve their problem by themselves and the poor insight into having a treatable condition [2], the stigma that prevents many of them from seeking treatment [3] and the poor knowledge of physicians regarding the available treatments [4]. However, the other reason is the low effectiveness of available treatments [5]. The development of new, more effective pharmacotherapies might contribute to increasing the number of subjects who seek and receive treatment.

R.A. and A.P. contributed equally to this work.

\section{KARGER}

E-Mail karger@karger.com

www.karger.com/ear
(C) 2013 S. Karger AG, Basel

$1022-6877 / 13 / 0196-0325 \$ 38.00 / 0$
Roberta Agabio, MD

Department of Biomedical Sciences, Section of Neuroscience, Clinical Pharmacology University of Cagliari, Cittadella Universitaria, SS 554, km. 4,500 IT-09042 Monserrato (Italy)

E-Mail agabio@unica.it 
Baclofen, a drug employed successfully for 40 years in the treatment of muscle rigidity, is one of the pharmacological agents currently under evaluation for the treatment of SUDs [6]. It has been reported that it reduces the severity of withdrawal symptoms and helps patients to achieve and maintain abstinence from some psychoactive drugs such as alcohol or cocaine. Accordingly, baclofen might be used both during detoxification and rehabilitation without requiring a change of the pharmacological agent on progressing from the first to the second phase and with the further advantage of being well known because of its long use as a muscle relaxant agent. Evidence of the effectiveness of baclofen would be particularly important in the case of several SUDs, including cocaine use disorders (CUDs) or cannabis use disorders, which currently lack any medically approved treatments.

However, to date, no review has been conducted on randomized, controlled trials (RCTs) on the effectiveness and safety of baclofen in the treatment of withdrawal syndrome and/or SUDs. Accordingly, the present study is aimed at (1) providing a brief description of the pharmacological features of baclofen, including safety information coming from clinical studies on its use as a muscle relaxant agent; (2) summarizing preclinical and clinical studies that have suggested its possible effectiveness in the treatment of withdrawal syndrome and/or SUDs, and (3) reviewing RCTs on baclofen use in the treatment of these disorders.

\section{Pharmacological Features of Baclofen}

\section{Clinical Uses of Baclofen}

Baclofen is indicated for the treatment of spasticity, and its wide use has underpinned the collection of information on its safety and side effects $[7,8]$. Its clinical benefits mainly relate to the reduction in flexor-extensor spasms, the reduction of mono- and polysynaptic reflexes and sphincter hyperreflexia [9]. It has been observed that baclofen also has analgesic/antinociceptive actions [7]. However, rapid tolerance to this effect has been observed, which has limited its use as an analgesic agent.

Baclofen has also been tested in the treatment of psychiatric disorders other than SUDs, with controversial results [10]. Namely, it was found to be effective in reducing the severity of anxiety in patients affected by panic disorders [11], posttraumatic stress disorder [12] and alcohol use disorders (AUDs) [13], as well as the severity of binge eating in women affected by bulimia or binge eating dis- order [14]. Conversely, it did not induce any effects in patients affected by schizophrenia $[15,16]$.

Baclofen was also tested with promising results in the treatment of other medical disorders such as cluster headaches [17], gastroesophageal reflux disease [18, 19], chronic hiccups [20] and cough [21].

\section{Pharmacodynamics}

\section{$\gamma$-Aminobutyric Acid Receptors $_{B}$}

$\gamma$-Aminobutyric acid (GABA; the major inhibitory neurotransmitter of the central nervous system) actives two different classes of receptors called $\mathrm{GABA}_{\mathrm{A}}$ and $\mathrm{GABA}_{\mathrm{B}}[21] . \mathrm{GABA}_{\mathrm{A}}$ receptors are the most prominent GABA receptor subtype and constitute the site of action of many centrally acting drugs such as benzodiazepines, barbiturates, neurosteroids, volatile anesthetics and alcohol [21]. $\mathrm{GABA}_{\mathrm{B}}$ receptors belong to the G-protein-coupled receptor family of metabotropic receptors [22]. They may be localized presynaptically (on bodies and/or dendrites of GABAergic and non-GABAergic neurons) or postsynaptically (on non-GABAergic neurons) [22]. Presynaptic $G_{A B A}$ receptors function as autoreceptors, inhibiting the release of GABA and many other neurotransmitters; postsynaptic $\mathrm{GABA}_{\mathrm{B}}$ receptors activate Gprotein-coupled enzymes which inhibit adenylyl cyclase, activate potassium channels, decrease calcium conductance, and produce neuronal hyperpolarization. The inhibitory action in the brain due to activation of $\mathrm{GABA}_{\mathrm{B}}$ receptors is believed to depend on a decrease in the release of excitatory amino acids (e.g. glutamate, via stimulation of presynaptic $\mathrm{GABA}_{\mathrm{B}}$ receptors) and a hyperpolarization of the postsynaptic neuron (via stimulation of postsynaptic $\mathrm{GABA}_{\mathrm{B}}$ receptors).

The prototypic $\mathrm{GABA}_{\mathrm{B}}$ receptor agonist is baclofen, a lipophilic GABA derivative that possesses a high affinity for the $\mathrm{GABA}_{\mathrm{B}}$ receptors [7]. Baclofen, also termed racemic baclofen ( $R, S$-baclofen), is an optically active compound, the $R$ isomer of which shows a threefold greater affinity for $\mathrm{GABA}_{\mathrm{B}}$ receptors and has a more efficient action than the racemate [23].

A binding site of positive allosteric modulation of $\mathrm{GABA}_{\mathrm{B}}$ receptors - topographically distinct from that of the neurotransmitter GABA - has been identified [24, 25]. Positive allosteric modulators (PAMs) of this site enhance the effects of GABA but are devoid of intrinsic agonistic activity [26]. However, baclofen is still the only drug acting on $\mathrm{GABA}_{\mathrm{B}}$ receptors currently available for clinical use [21]. 
Possible Mechanism of Action in the Treatment of SUDs

Substances of abuse powerfully stimulate the mesolimbic dopaminergic system, the likely neuronal system mediating the reinforcing, motivational, stimulating and rewarding properties of these substances [27]. Neuroanatomically, this 'reward' system is constituted of dopaminergic neurons originating in the ventral tegmental area and terminating in the nucleus accumbens and amygdala. These neurons receive GABAergic inputs which have an inhibitory effect on dopaminergic tone that may reduce the reinforcing effects of substances of abuse [27].

Several lines of evidence indicate that alcohol withdrawal hyperexcitability is associated with increased function of the N-methyl-D-aspartate subtype of glutamate receptor [28]. The inhibitory action of the $\mathrm{GABA}_{\mathrm{B}}$ receptor system on neurotransmission also involves the regulation of excitatory amino acid functions; for instance, presynaptic $\mathrm{GABA}_{B}$ receptors may inhibit glutamate release, while postsynaptic $G_{A B A}$ receptors may hyperpolarize postsynaptic neurons [29].

\section{Pharmacokinetics}

Baclofen is available in formulations that can be orally or intrathecally administered (intrathecal baclofen administration, ITBA). The recommended oral daily dose for baclofen ranges from 15 to $80 \mathrm{mg}$, starting from $5 \mathrm{mg}, 3$ times a day, and gradually increasing by $5 \mathrm{mg}$ 3 times daily, every 3 days, until the optimum dose is achieved. Higher daily doses, up to $120 \mathrm{mg}$, should only be administered to hospitalized patients. Baclofen is rapidly absorbed after oral administration, and up to $80 \%$ of an oral dose is excreted in the urine, with only a limited hepatic metabolism [30]. Baclofen urinary excretion is related to creatinine clearance [31]. Baclofen has a short half-life, ranging from 2 to $6 \mathrm{~h}$, and needs to be administered 3 or 4 times per day to maintain its therapeutic effects [23]. It has poor brain penetration, and many patients require dosages exceeding $80 \mathrm{mg}$, with a mean daily dose ranging from $140 \mathrm{up}$ to $280 \mathrm{mg}$ [32]. The pharmacokinetics of high-dose baclofen is characterized by a longer half-life [30]. The half-life is also increased in patients with renal insufficiency [33-35]. Approximately $25 \%$ of patients with spasticity are unresponsive even to higher oral doses of baclofen and require ITBA [36]. This latter route of administration is more invasive, expensive and prone to complications than oral administration but requires very much lower doses (approximately 1\% of the dose used for oral administration) [37].

\section{Side Effects}

Side effects of oral baclofen administration are generally mild and transient, and baclofen tolerability is generally considered to be good [8]. When given orally, the incidence of side effects ranges from 10 to $75 \%$ [8]. The most common side effects include sedation or somnolence, excessive weakness and vertigo. Symptoms are rarely severe and frequently subside or disappear with continued therapy. They are dose related (usually appearing at dosages higher than $60 \mathrm{mg}$ a day) and may be minimized by initiating treatment at a low dose and gradually titrating upward [8]. However, as baclofen is predominantly eliminated by the kidneys, patients with impaired renal function are at particular risk of accumulation even with low-dose therapy $[33,34]$.

\section{Intoxication}

High baclofen levels are usually well tolerated if the dosage is increased gradually; for this reason, rapid increases should be avoided [8]. Oral baclofen intoxication is usually due to an error of administration, attempted suicide or impaired renal function, while intoxication after ITBA is usually due to human error in pump programming or refill [8]. Very few cases of voluntary abuse of baclofen for reasons other than attempted suicide have been described [38-40].

Symptoms of acute baclofen intoxication include nausea, hypotonia, dizziness, respiratory depression, coma, seizures, cardiac conduction abnormalities and EEG abnormalities [41]. The outcome of baclofen intoxication is generally good, and a large number of studies have reported a complete recovery of patients even after episodes of coma [41-51]. However, baclofen intoxication can be life-threatening, and fatal cases of baclofen intoxication have also been described [40,52]. Due to the lack of a specific antidote, clinical management of baclofen intoxication is primarily supportive. Recent studies suggest that hemodialysis and lumbar puncture may be used to decrease baclofen levels in blood and cerebrospinal fluid, respectively $[53,54]$. 


\section{Withdrawal}

Cessation of long-term baclofen administration may cause severe withdrawal syndrome after either oral administration or ITBA [55]. The symptoms of withdrawal are most often limited to return of the patient's baseline rigidity [8]. In more severe cases, symptoms may include seizures, acute psychosis, delirium, fever, labile blood pressure or hypotension and lowering of consciousness [56-63]. These symptoms usually improve after the reintroduction of baclofen; other treatment options may be benzodiazepines, propofol, skeletal muscle relaxants and tizanidine [61]. A few fatal cases of baclofen withdrawal syndromes have been described $[64,65]$. The risk of withdrawal symptoms may be minimized by avoiding the abrupt discontinuation of therapy, reducing the dose by $5 \mathrm{mg}, 3$ times a day every 3 days, until termination of therapy.

\section{Baclofen and SUDs}

\section{Methods of Searching for RCTs}

A systematic search was conducted on PubMed/Medline for the time period January 1990 to December 2012 using the following keywords: baclofen and alcohol OR baclofen and substance use disorders AND humans. Only studies in humans assessing the effectiveness of baclofen in SUDs and withdrawal were considered. Abstracts of retrieved articles were scanned to identify studies matching the inclusion criteria. References of retrieved articles and reviews on the topic were also examined to identify other possible relevant studies. Articles were excluded if they were unrelated to the topic, written in a language other than English or were letters, comments or single case reports on side effects occurring in patients using baclofen for the treatment of neurological disorders.

\section{Methods Used to Evaluate the Efficacy of Baclofen}

Medical treatment of SUDs is aimed at achieving total abstinence from substance use [66]. However, when failing to achieve the latter, even a reduction in use of the substance is viewed as a good result as it decreases the risks related to frequent use of excessive amounts of the substance. Accordingly, the effects of baclofen were considered positive when administration significantly suppressed or reduced use of the psychoactive substance.
Data on RCTs were summarized in tables. When possible, a meta-analysis was carried out using Comprehensive Meta-Analysis (version 2.2) software. For categorical variables (e.g. dropouts), an odds ratio or relative risk with $95 \%$ confidence interval (CI) was extracted. For continuous variables (e.g. variations in levels of $\gamma$-glutamyltranspeptidase before and after treatment), Hedges' g with 95\% CI was calculated.

The quality of studies was assessed by use of the Cochrane risk of bias tool [67]. Heterogeneity was assessed by means of Cochran's Q ( $p<0.05$ was interpreted as suggestive of heterogeneity) and $\mathrm{I}^{2}$ statistics, which can be interpreted as the proportion of total variation in study estimates independent of sampling errors (values between 30 and $60 \%$ were considered indicative of moderate heterogeneity) [68]. A funnel plot was also inspected for evidence of asymmetry and as a proxy index of heterogeneity [69]. The issue of heterogeneity, if detected, was addressed using the trim and fill method [70]. A small shift in the trim-and-fill-adjusted effect size indicates good accuracy of the initial effect size.

The random-effect model was reported at preference. The value of $\tau^{2}$, the between-studies variance or variance of the effect size parameters across the population considered, was calculated [71]. The random-effect analysis coincides with the fixed-effect model when the $\tau^{2}$ is zero and departs from this when $\tau^{2}$ is 0.10 or higher. In the case of a statistically significant result, the classical fail-safe ' $n$ ' was calculated; this is the minimum number of additional null studies required to make the result no longer significant on statistical grounds [71]. According to Rosenthal [72], an effect size can be regarded as robust if the fail-safe number exceeds $5 K+10$, where $\mathrm{K}$ is the number of studies included in the metaanalysis.

\section{Results of the Search}

Figure 1 shows a flowchart of the search strategy. Overall, 52 articles were assessed. Among them, 12 articles were selected as they specifically referred to RCTs [73-84]. In fact, these articles described 11 RCTs because 2 of them referred to the same RCT [76, 77]. In detail, 4 RCTs were on AUDs [73-75, 80], 2 RCTs were on the treatment of withdrawal from alcohol or other substances $[76,77,83], 2$ RCTs were on the treatment of CUDs $[82,84], 1$ RCT was on the treatment of opioid use disorders [78], 1 RCT was on the treatment of nicotine use disorders (NUDs) [79] and the last RCT was on the treat- 
Fig. 1. Flowchart indicating the search strategy and classification of articles.

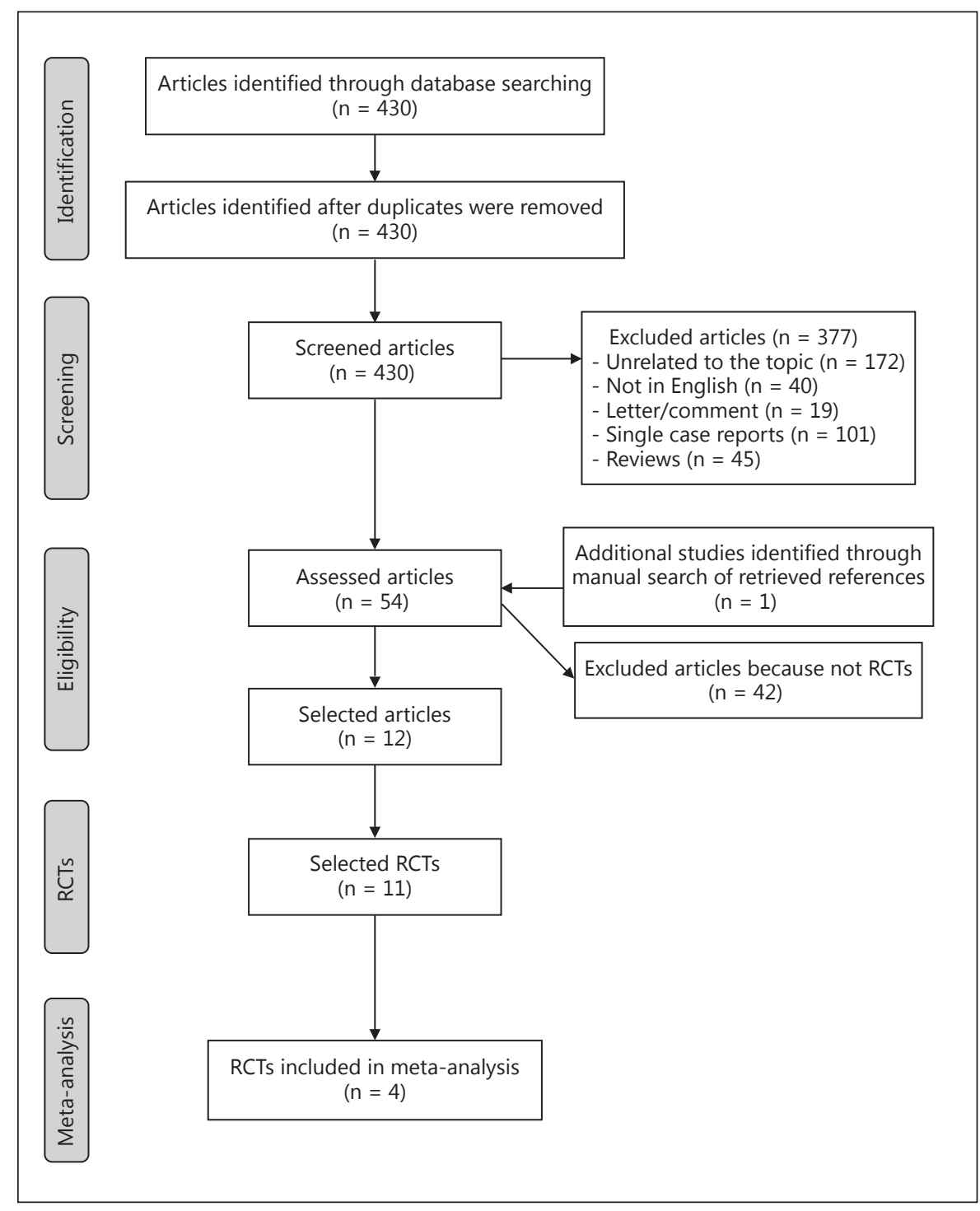

ment of methamphetamine use disorders [81]. Details of these RCTs are shown in tables 1-3.

Among the 4 RCTs focusing on AUDs, 2 found baclofen to be effective [73, 74], 1 study found it ineffective [80] and 1 study did not achieve the preplanned level of participation [75]. Among the other 7 RCTs, 3 studies found that baclofen is effective in the treatment of alcohol withdrawal syndrome (AWS; 1 study out of 1) [83], heroin withdrawal syndrome (1 study out of 1$)[76,77]$ and NUDs (1 study out of 1) [79], whilst 4 studies found it to be ineffective in the treatment of CUDs (2 studies out of 2 ) $[82,84]$, opioid use disorders (1 study out of 1 ) [78] and methamphetamine use disorders (1 study out of 1) [81].
All the RCTs showed that baclofen is devoid of particularly serious side effects, except 2 studies in which 4 patients experienced adverse effects requiring hospitalization $[82,84]$; however, in one of them, 2 patients from the placebo group also required hospitalization because of side effects [82].

The 4 RCTs on AUDs allowed us to attempt a metaanalysis of findings. For descriptive purposes only, the results of random-effect model meta-analysis concerning retention in treatment (dropout) and abstinence are reported. $\gamma$-Glutamyltranspeptidase levels were reported in only 3 out 4 studies; this prevented their analysis. Regarding dropout, a nonsignificant lower risk was de- 
Table 1. RCTs of AUDs

\begin{tabular}{|c|c|c|c|c|}
\hline Study & Addolorato et al. [73] & Addolorato et al. [74] & Garbutt et al. [80] & Addolorato et al. [75] \\
\hline Year & $2000-2001$ & 2003-2006 & NA & 2006-2007 \\
\hline Location & Rome and Bologna (Italy) & Rome (Italy) & Chapel Hill, N.C. (USA) & Rome (Italy) \\
\hline Setting & alcohol treatment units & Institute of Internal Medicine & Center for Alcohol Studies & Institute of Internal Medicine \\
\hline Type of sample & all consecutive admissions & all consecutive admissions & convenience (advertisement) & all consecutive admissions \\
\hline Diagnosis & alcohol dependence & $\begin{array}{l}\text { alcohol dependence and } \\
\text { cirrhosis }\end{array}$ & alcohol dependence & alcohol dependence \\
\hline Criteria for diagnosis & DSM-IV & DSM-IV & DSM-IV & DSM-IV TR \\
\hline$\underline{\text { Sample }}$ & $\mathrm{n}=39$ out of 76 assessed & $\mathrm{n}=84$ out of 148 screened & $\mathrm{n}=80$ out of 121 assessed & $\mathrm{n}=42$ out of 94 assessed \\
\hline Males, $\mathrm{n}$ & $34(87.2 \%)$ & $61(72.6 \%)$ & $44(55.0 \%)$ & $32(76.2 \%)$ \\
\hline Age, years & $47.3 \pm 1.7$ & $51.1 \pm 1.2$ & NA & $43.9 \pm 1.4^{\mathrm{b}}$ \\
\hline Randomization & alternation of letters & blocks & $\begin{array}{l}\text { number generator and stratified } \\
\text { on gender }\end{array}$ & alternation of letters \\
\hline Sample & baclofen: $\mathrm{n}=20$ & baclofen: $n=42$ & baclofen: $n=40$ & baclofen $10 \mathrm{mg}: \mathrm{n}=14$ \\
\hline Age, years & $45.8 \pm 2.4$ & $51.3 \pm 1.7^{\mathrm{b}}$ & $47.5 \pm 1.2$ & $45.6 \pm 2.5$ \\
\hline \multirow[t]{5}{*}{ Males, n } & $17(85.0 \%)$ & $29(69.0 \%)$ & $22(55.0 \%)$ & $12(85.7 \%)$ \\
\hline & & & & $\begin{array}{l}\text { baclofen } 20 \mathrm{mg}: \mathrm{n}=14 \\
43.1 \pm 1.9 \\
9(64.3 \%)\end{array}$ \\
\hline & placebo: $\mathrm{n}=19$ & placebo: $\mathrm{n}=42$ & placebo: $\mathrm{n}=40$ & placebo: $\mathrm{n}=14$ \\
\hline & $48.8 \pm 2.4$ & $50.9 \pm 1.6^{\mathrm{b}}$ & $50.3 \pm 1.1$ & $43.1 \pm 2.7$ \\
\hline & $17(89.5 \%)$ & $32(76.2 \%)$ & $22(55.0 \%)$ & $11(78.6 \%)$ \\
\hline \multirow[t]{2}{*}{ Daily drinks $^{\mathrm{a}}, \mathrm{n}$} & baclofen: $17.6 \pm 1.7$ & baclofen: $18.0 \pm 1.0^{\mathrm{b}}$ & baclofen: $7.3 \pm 0.6$ & $\begin{array}{l}\text { baclofen } 10 \mathrm{mg}: 19.3 \pm 1.5^{\mathrm{b}} \\
\text { baclofen } 20 \mathrm{mg}: 20.1 \pm 2.7^{\mathrm{b}}\end{array}$ \\
\hline & placebo: $10.7 \pm 1.5$ & placebo: $17.5 \pm 0.9^{\mathrm{b}}$ & placebo: $6.9 \pm 0.5$ & placebo: $22.2 \pm 2.5^{\mathrm{b}}$ \\
\hline \multirow{2}{*}{$\begin{array}{l}\text { Duration of } \\
\text { dependence } \\
\text { years }\end{array}$} & baclofen: $12.6 \pm 1.1$ & baclofen: $23.0 \pm 1.4^{\mathrm{b}}$ & baclofen: $23.5 \pm 1.6$ & $\begin{array}{l}\text { baclofen } 10 \mathrm{mg}: 16.1 \pm 2.3 \\
\text { baclofen } 20 \mathrm{mg}: 12.6 \pm 2.2\end{array}$ \\
\hline & placebo: $11.0 \pm 0.9$ & placebo: $22.5 \pm 1.2^{\mathrm{b}}$ & placebo: $27.9 \pm 1.6$ & placebo: $11.6 \pm 2.7$ \\
\hline Baclofen dose & 10 mg t.i.d. (30 mg/day) & 10 mg t.i.d. (30 mg/day) & 10 mg t.i.d. (30 mg/day) & $\begin{array}{l}10 \mathrm{mg} \text { t.i.d. (30 mg/day) } \\
20 \mathrm{mg} \text { t.i.d. ( } 60 \mathrm{mg} / \text { day) }\end{array}$ \\
\hline Duration of treatment & 30 days & 12 weeks & 12 weeks & 12 weeks \\
\hline \multirow[t]{2}{*}{ Dropouts, $\mathrm{n}$} & baclofen: $3(15 \%)$ & baclofen: $6(14 \%)$ & baclofen: $12(30 \%)$ & $\begin{array}{l}\text { baclofen } 10 \mathrm{mg}: 2(14 \%) \\
\text { baclofen } 20 \mathrm{mg}: 2(14 \%)\end{array}$ \\
\hline & placebo: $8(42 \%)$ & placebo: $13(31 \%)$ & placebo: $8(20 \%)$ & placebo: $6(42 \%)$ \\
\hline Criteria for abstinence & $\begin{array}{l}\text { patient self-report } \\
\text { family interview } \\
\text { alcohol concentration in blood } \\
\text { and saliva }\end{array}$ & $\begin{array}{l}\text { patient self-report } \\
\text { family interview } \\
\text { alcohol concentration in blood } \\
\text { and/or urine }\end{array}$ & NA & TLFB \\
\hline Criteria for CAD & total number of days of abstinence & $\begin{array}{l}\text { total number of days of } \\
\text { abstinence }\end{array}$ & NA & $\begin{array}{l}\text { total number of days } \\
\text { of abstinence }\end{array}$ \\
\hline \multirow{2}{*}{$\begin{array}{l}\text { Reached and } \\
\text { maintained } \\
\text { abstinence }^{c}, \mathrm{n}\end{array}$} & baclofen: 14/20 (70\%) & baclofen: 30/42 (71\%) & baclofen: $4 / 40(10 \%)^{\mathrm{d}}$ & $\begin{array}{l}\text { baclofen } 10 \mathrm{mg}: 11 / 14(78.6 \%) \\
\text { baclofen } 20 \mathrm{mg}: 11 / 14(78.6 \%)\end{array}$ \\
\hline & placebo: $4 / 19(21 \%)$ & placebo: $12 / 42(29 \%)$ & placebo: $1 / 40(2 \%)^{\mathrm{d}}$ & placebo: $6 / 14(42.9 \%)$ \\
\hline \multirow[t]{2}{*}{ CAD, days } & baclofen: $19.6 \pm 2.6$ & baclofen: $62.8 \pm 5.4$ & baclofen: NA & $\begin{array}{l}\text { baclofen } 10 \mathrm{mg}: 78.3 \pm 3.5 \\
\text { baclofen: } 20 \mathrm{mg}: 79.3 \pm 3.6\end{array}$ \\
\hline & placebo: $6.3 \pm 2.4$ & placebo: $30.8 \pm 5.5$ & placebo: NA & placebo: $63.9 \pm 7.8$ \\
\hline \multirow[t]{4}{*}{ GGT, U/l } & $\begin{array}{l}\text { baclofen: } \mathrm{n}=16 \\
\text { pretreatment: } 150.9 \pm 41.8 \\
\text { posttreatment: } 56.9 \pm 16.7\end{array}$ & $\begin{array}{l}\text { baclofen: } \mathrm{n}=36 \\
\text { pretreatment: } 264.1 \pm 49.7 \\
\text { posttreatment: } 54.9 \pm 10.0\end{array}$ & $\begin{array}{l}\text { baclofen: assessed } \\
\text { but NA }\end{array}$ & $\begin{array}{l}\text { baclofen } 10 \mathrm{mg}: \mathrm{n}=12 \\
\text { pretreatment: } 304.2 \pm 87.2 \\
\text { posttreatment: } 109.0 \pm 70.0\end{array}$ \\
\hline & & & & $\begin{array}{l}\text { baclofen } 20 \text { mg: } \mathrm{n}=12 \\
\text { pretreatment: } 153.1 \pm 66.7 \\
\text { posttreatment: } 81.6 \pm 42.4\end{array}$ \\
\hline & placebo: $\mathrm{n}=11$ & placebo: $\mathrm{n}=29$ & placebo: assessed & placebo: $\mathrm{n}=8$ \\
\hline & $\begin{array}{l}\text { pretreatment: } 103.6 \pm 24.8 \\
\text { posttreatment: } 50.5 \pm 11.2\end{array}$ & $\begin{array}{l}\text { pretreatment: } 245.1 \pm 39.8 \\
\text { posttreatment: } 99.4 \pm 23.3\end{array}$ & but NA & $\begin{array}{l}\text { pretreatment: } 357.5 \pm 243.5 \\
\text { posttreatment: } 236.3 \pm 213.0\end{array}$ \\
\hline
\end{tabular}


Table 1 (continued)

\begin{tabular}{|c|c|c|c|c|}
\hline Study & Addolorato et al. [73] & Addolorato et al. [74] & Garbutt et al. [80] & Addolorato et al. [75] \\
\hline \multirow[t]{2}{*}{ Side effects } & $\begin{array}{l}\text { baclofen: } \\
\text { sleepiness, tiredness, vertigo; } \\
\text { no serious event leading to } \\
\text { drug cessation; no withdrawal } \\
\text { syndrome on drug suspension }\end{array}$ & $\begin{array}{l}\text { baclofen: } \\
\text { headache, tiredness, vertigo, } \\
\text { sleepiness; no serious event } \\
\text { leading to drug cessation; } \\
\text { no withdrawal syndrome on } \\
\text { drug suspension }\end{array}$ & $\begin{array}{l}\text { baclofen: } \\
\text { mild adverse effects; } 28 \% \text { had } \\
\text { drowsiness, } 3 \% \text { headache; } \\
3 \text { stopped medication due to } \\
\text { side effects }\end{array}$ & $\begin{array}{l}\text { baclofen } 10 \text { mg: } \\
\text { headache, sleepiness, abdominal } \\
\text { pain, constipation, insomnia } \\
\text { baclofen } 20 \text { mg: } \\
\text { headache, sleepiness, tiredness, } \\
\text { vertigo, drowsiness; } 1 \text { patient } \\
\text { required a dose reduction to } 10 \\
\text { mg per day due to severe fatigue }\end{array}$ \\
\hline & $\begin{array}{l}\text { placebo: } \\
\text { abdominal pain }\end{array}$ & $\begin{array}{l}\text { placebo: } \\
\text { headache, tiredness, vertigo }\end{array}$ & $\begin{array}{l}\text { placebo: } \\
10 \% \text { headache or drowsiness }\end{array}$ & $\begin{array}{l}\text { placebo: } \\
\text { headache, sleepiness, tiredness, } \\
\text { abdominal pain, nausea }\end{array}$ \\
\hline Results & $\begin{array}{l}\text { baclofen significantly reduced } \\
\text { alcohol consumption and craving }\end{array}$ & $\begin{array}{l}\text { baclofen significantly } \\
\text { increased abstinence }\end{array}$ & $\begin{array}{l}\text { baclofen and placebo treatments } \\
\text { did not differ in regard to alcohol } \\
\text { consumption and craving }\end{array}$ & $\begin{array}{l}\text { the study did not achieve the } \\
\text { preplanned level of participation }\end{array}$ \\
\hline $\begin{array}{l}\text { Effect size of baclofen } \\
\text { vs. placebo in inducing } \\
\text { abstinence, OR } \\
(95 \% \mathrm{CI})\end{array}$ & $11.2(2.5-50.3)$ & $6.2(2.4-16.1)$ & $4.3(0.4-40.6)$ & $4.9(0.9-25.7)^{\mathrm{e}}$ \\
\hline $\begin{array}{l}\text { Effect size of baclofen } \\
\text { vs. placebo in reducing } \\
\text { the number of } \\
\text { dropouts, RR ( } 95 \% \mathrm{CI})\end{array}$ & $0.3(0.1-1.1)$ & $0.4(0.19-1.09)$ & $1.5(0.7-3.3)$ & $0.3(0.1-1.4)^{\mathrm{e}}$ \\
\hline
\end{tabular}

Values represent means \pm standard errors, except where indicated otherwise. CAD = Cumulative abstinence duration; DSM = Diagnostic and Statistical Manual of Mental Disorders; TR = text revision; GGT = $\gamma$-glutamyltranspeptidase; NA = not available; TLFB = timeline followback; OR = odds ratio; RR = relative risk.

${ }^{\mathrm{a}} 1$ drink $=12 \mathrm{~g}$ of ethanol.

b Data provided by the authors of the paper.

${ }^{c}$ Abstinence defined as at least 4 consecutive weeks (28 days) without lapse and/or relapse.

${ }^{\mathrm{d}}$ Reconstructed from a figure.

${ }^{\mathrm{e}}$ Results concern the group receiving baclofen $10 \mathrm{mg}$ t.i.d. (30 mg/day), to assure comparability with past studies.

tected in the baclofen group compared to the placebo group in the 4 studies (risk ratio $=0.59,95 \% \mathrm{CI}=0.27$ 1.28; $\mathrm{z}=-1.330, \mathrm{p}=0.18$ ). Heterogeneity was substantial $\left(\mathrm{Q}=6.86\right.$, degrees of freedom $=3, \mathrm{p}=0.076 ; \mathrm{I}^{2}=$ $56 \%)$.

Regarding abstinence, the random-effect model showed an advantage for baclofen versus placebo (odds ratio $=6.55,95 \% \mathrm{CI}=3.29-13.00 ; \mathrm{z}=5.37, \mathrm{p}=0.000 ; \tau=$ $50 \%)$. Heterogeneity was absent $(\mathrm{Q}=0.76$, degrees of freedom $\left.=3, \mathrm{p}=0.86 ; \mathrm{I}^{2}=0 \%\right)$. The classical fail-safe $\mathrm{n}$ was 23 , which is lower than the threshold for robustness $(5 \times 4+10=30)$. It should be noted that data on abstinence in the study by Garbutt et al. [80] were calculated from a figure and may therefore not be reliable. Overall, the quality of studies was judged as low to moderate, since it was compromised in a number of ways (table 4). Procedures for blinding of participants and personnel were not clearly explained, and selective reporting of outcome and other biases occurred in some studies. However, the study with the best quality [74] was also the one reporting greater effectiveness of baclofen.

Efficacy and Tolerability of Baclofen in Substance Use Disorders
The low number of studies undertaken to evaluate the safety and effectiveness of baclofen in the treatment of withdrawal syndrome from alcohol or other substances as well as in the treatment of SUDs with substances other than alcohol did not permit statistical analysis.

\section{Description of Studies}

\section{Alcohol Use Disorders}

Preclinical Studies

A large body of experimental evidence suggests that acute and/or repeated treatment with nonsedative doses of baclofen reduces several alcohol-related behaviors in laboratory animals exposed to multiple experimental procedures that model different aspects of AUDs in humans. Specifically, treatment with baclofen has been reported to suppress the following: (1) alcohol drinking in rats exposed to the standard, home cage 2-bottle 'alcohol versus water' choice regimen (a validated animal model of excessive alcohol consumption in humans) [29, 85- 

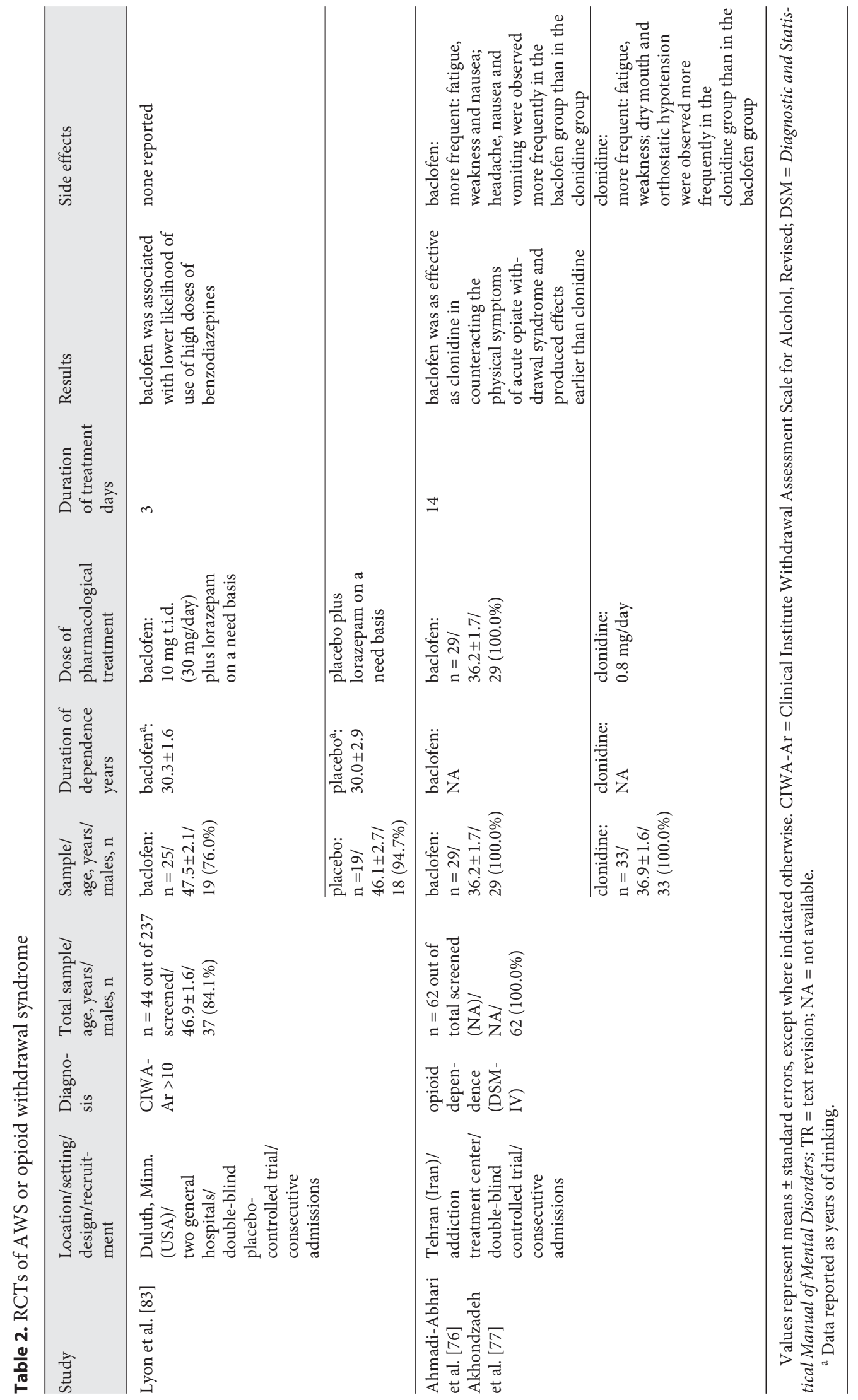


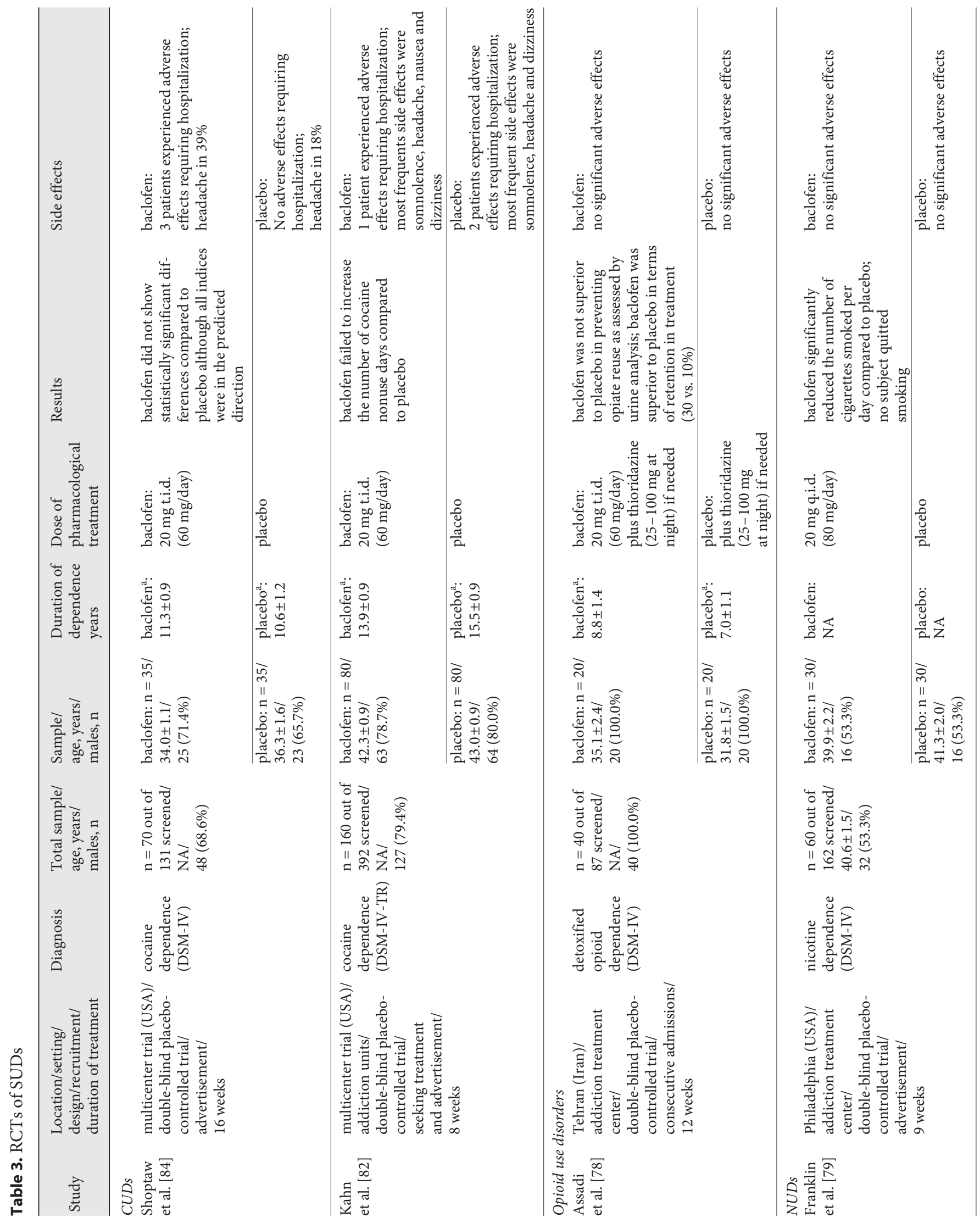




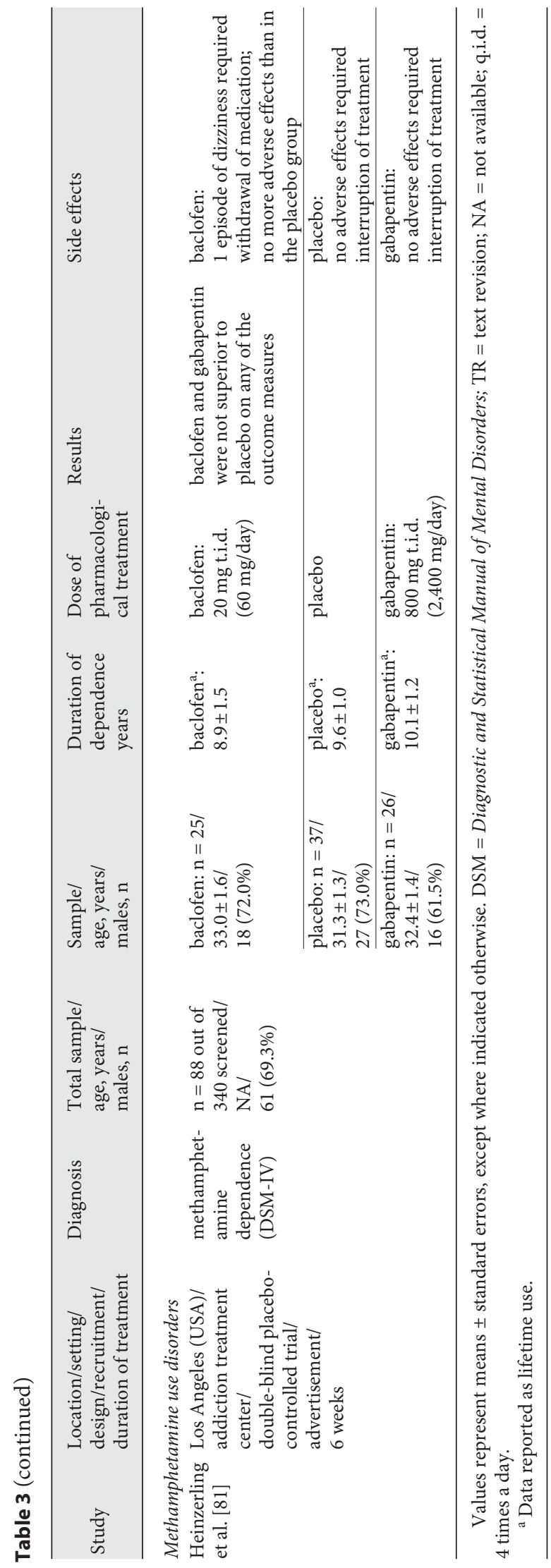

88]; (2) relapse-like drinking in previously abstinent rats [89, 90]; (3) alcohol reinforcing and motivational properties in rats, mice and nonhuman primates trained to perform a given amount of 'work' (usually responding on a lever) to gain access to the alcohol solution [91-99]; (4) reinstatement of alcohol-seeking behavior triggered in rats by the noncontingent presentation of a complex of cues previously associated with alcohol availability [100]; (5) alcohol-induced conditioned place preference (CPP; index of alcohol rewarding properties) in mice [101], and (6) alcohol-induced stimulation of locomotor activity in rats and mice (index of alcohol euphorigenic properties) [102-105].

Conversely, a few studies provided data suggesting that low doses of baclofen $(0.125$ and $1.0 \mathrm{mg} / \mathrm{kg})$ may stimulate, rather than decrease, alcohol self-administration in unselected rats $[106,107]$.

Finally, one study demonstrated the existence of crosstolerance to the sedative effects of alcohol and baclofen; alcohol-tolerant mice were less sensitive to the sedative effects of baclofen than alcohol-naive mice [92].

\section{Clinical Studies}

Case Report Studies. Three case reports showed that the oral administration of baclofen doses ranging between 75 and $125 \mathrm{mg} /$ day was effective in the treatment of AUDs [108-110]. Two other case reports found that baclofen administration (from 30 to $400 \mathrm{mg}$ daily) was also effective in reducing or suppressing alcohol consumption in patients affected by AUDs and other psychiatric illnesses in whom previous treatment with other drugs had been unsuccessful $[111,112]$.

Open Studies. Two open-label studies have been published so far on the effectiveness of baclofen in the treatment of AUDs; the first trial recruited 10 men affected by AUDs and lasted for 4 consecutive weeks [113], and the second study recruited 12 subjects affected by AUDs (3 women and 9 men) and lasted 12 consecutive weeks [114]. Both the studies used $10 \mathrm{mg}$ of baclofen 3 times a day (t.i.d.; equal to $30 \mathrm{mg} /$ day) and found that baclofen is effective in reducing daily drinking and episodes of heavy daily drinking. The first study also found that baclofen reduced obsessional thinking about alcohol [113]. However, the second one did not report achieving and maintaining abstinence in any patient [114].

Observational Studies. Two observational studies found that the administration of escalating doses of baclofen (up to $330 \mathrm{mg} /$ day, average effective dose $147 \mathrm{mg} /$ day) reduced or suppressed alcohol craving in the majority of patients affected by AUDs who were resistant to the 
usual treatment even after long periods of observation $[115,116]$.

Laboratory Studies. In a laboratory study, baclofen (up to $80 \mathrm{mg}$ ) was acutely administered $2.5 \mathrm{~h}$ before an intoxicating dose of alcohol or alone in heavy social drinkers [117]. In this study, subjects were asked to reply to questions investigating craving for alcohol and the effects perceived after alcohol consumption. They were also asked to perform computerized tasks aimed at investigating various aspects of functions that may be impaired by alcohol, baclofen and/or a combination of the two, including memory, vigilance and psychomotor abilities. The results of the study showed that both baclofen and alcohol administration increased sedation and impaired psychomotor abilities; however, performance was not impaired to any greater extent when baclofen was combined with alcohol. This result has been confirmed by a recent laboratory study [118] in which 14 heavy drinkers were requested to perform different tasks following a 7 -day period of baclofen treatment $(30 \mathrm{mg} /$ day). The results showed that the combination of baclofen and alcohol did not induce the onset of significant sedation, tiredness and sleepiness. Taken together, the results of these laboratory studies suggest a potentially acceptable safety profile for baclofen even if subjects continue to drink.

Randomized Studies. Four randomized studies have been carried out to assess the effectiveness of baclofen in the treatment of AUDs; 2 studies were carried out in Italy, a third was performed in the USA and the last was an international, multicenter study [73-75, 80] (table 1). The first Italian trial found that baclofen treatment increased the number of patients displaying complete abstinence and decreased alcohol consumption in patients who did not achieve complete abstinence [73]. Baclofen also reduced craving and anxiety scores. The second Italian trial also found that relatively low doses of baclofen were effective in the treatment of severe alcohol-dependent patients affected by liver cirrhosis [74]. Baclofen treatment increased the number of patients achieving and maintaining complete abstinence as well as the duration of abstinence and reduced the alcohol-craving score. In the US trial, baclofen and placebo treatments did not show significant differences in (1) rate of heavy drinking days, (2) rate of abstinent days or (3) alcohol craving score [80]. Conversely, baclofen treatment reduced anxiety scores. Methodological differences between the studies may, at least in part, explain the divergent results collected in the Italian and US double-blind studies, such as (1) the higher number of women recruited in the US study compared to the Italian studies; (2) the presence of additional psy-

Efficacy and Tolerability of Baclofen in Substance Use Disorders chiatric disorders in the US study; (3) the different procedure of recruitment (treatment-seeking patients in the Italian studies, advertisements in newspapers in the US study), and (4) the different mean number of daily drinks at the start of baclofen treatment [119]. The last trial was an international, multicenter study that did not achieve the preplanned level of participation and did not find any significant difference in effect on abstinence between baclofen and placebo, although in the Italian arm of the study baclofen was found to produce a dose-response effect on the reduction of alcohol intake [75]. All these studies used relatively low doses of baclofen (30 or $60 \mathrm{mg}$ per day) compared to doses reported to suppress alcohol use in observational studies (up to $330 \mathrm{mg}$ per day) $[115,116]$. In these studies, side effects were tolerable, mild to moderate - also in patients affected by liver cirrhosis - and no study reported the occurrence of a withdrawal syndrome after baclofen suspension or craving for baclofen (table 1).

\section{Alcohol Withdrawal Syndrome}

Preclinical Studies

Some preclinical studies showed that baclofen administration effectively reduces the intensity of different signs of AWS, including anxiety-related behaviors, tremors and seizures, in alcohol-dependent rats $[29,120,121]$. Baclofen-induced activation of $\mathrm{GABA}_{\mathrm{B}}$ receptors might counterbalance withdrawal-associated, enhanced function of glutamate excitatory neurotransmission [29]. Conversely, a preclinical study found that baclofen administration had no effects on alcohol withdrawal in female mice [122].

\section{Clinical Studies}

Case Reports and Retrospective Studies. A first study conducted on 5 patients ( 4 men and 1 woman) diagnosed with AWS found that the administration of $10 \mathrm{mg}$ of baclofen led to a discontinuation of withdrawal symptoms and relieved psychological distress with rapid improvement of well-being [123]. Patients were maintained at $10 \mathrm{mg}$ of baclofen every $8 \mathrm{~h}$ during a 30-day follow-up period and maintained abstinence without reporting significant side effects. The same authors also reported the ability of baclofen ( $25 \mathrm{mg}$ t.i.d.) to stop delirium tremens in 1 patient [124]. A study based on retrospective chart review found that baclofen administration prevented the development of AWS in 12 cases out of 17 [125]. However, the study did not provide details on the dosage used.

Randomized Studies. An open, comparative study found that baclofen was as effective as diazepam in reduc- 
Table 4. Risk of bias in RCTs of AUDs

\begin{tabular}{lllllll}
$\begin{array}{l}\text { Addolorato } \\
\text { et al. [73] }\end{array}$ & $\begin{array}{l}\text { Addolorato } \\
\text { et al. [74] }\end{array}$ & $\begin{array}{l}\text { Garbutt } \\
\text { et al. [80] }\end{array}$ & $\begin{array}{l}\text { Addolorato } \\
\text { et al. [75] }\end{array}$ & L & U & H \\
\hline
\end{tabular}

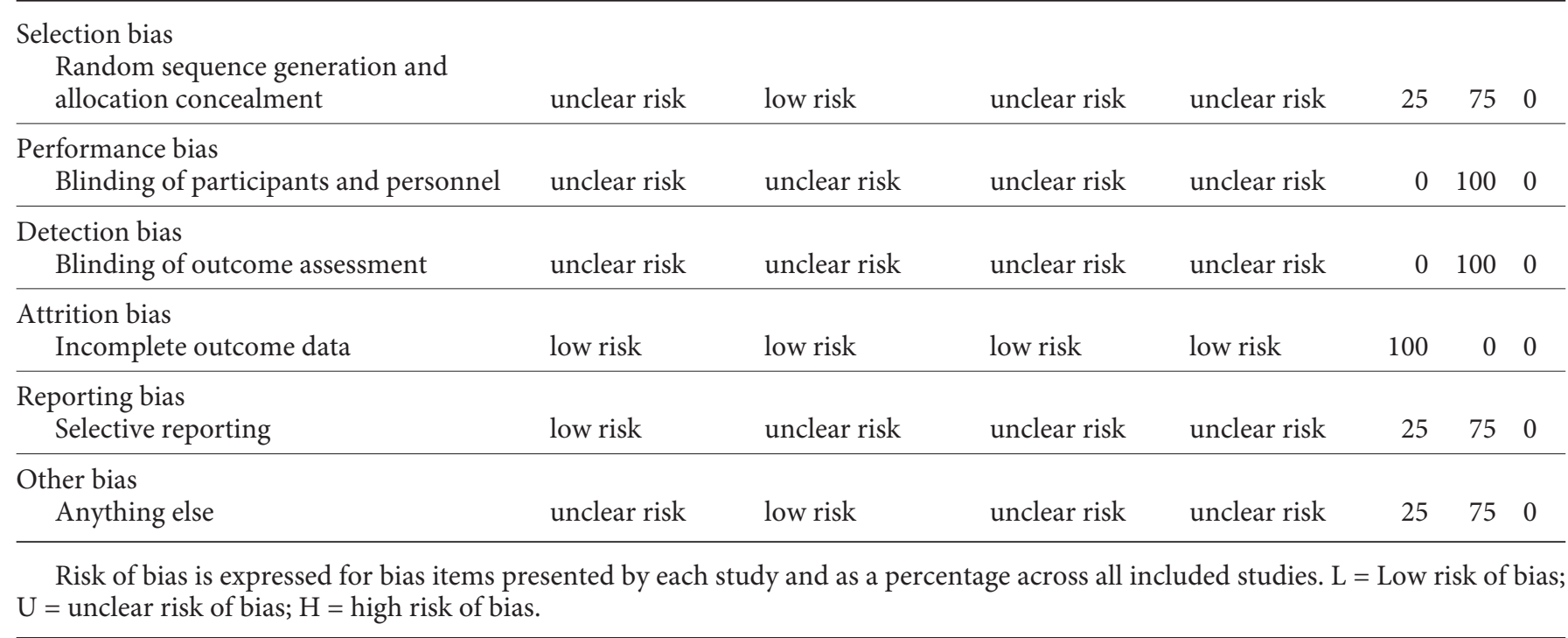

ing the severity of AWS, with diazepam being more rapid in reducing agitation when present [126]. No side effects were reported by either group. This study was the only one included in the recent Cochrane review aimed at evaluating the efficacy of baclofen in the treatment of AWS [127]. Despite the positive results obtained in this single study, evidence for recommending baclofen in the treatment of AWS was considered insufficient by the authors of the review. A subsequent RCT confirmed the effectiveness of baclofen compared to placebo in reducing the intensity of AWS [83]. Namely, this study, in which all subjects received symptom-triggered benzodiazepines, found that baclofen reduced the use of benzodiazepines in the management of AWS over $72 \mathrm{~h}$ of observation (table 2).

\section{Cocaine Use Disorders}

Preclinical Studies

Treatment with baclofen, administered both systemically and into a specific area of the brain 'reward' system, has repeatedly been reported to reduce intravenous cocaine self-administration in rats trained to lever-respond for cocaine [128-132]. However, it has also been found that baclofen administration does not attenuate the discriminative stimulus effects (corresponding to the subjective human feelings elicited by a psychoactive drug) of cocaine [133].

\section{Clinical Studies}

Case Reports and Open Studies. The first observation of a certain degree of effectiveness of baclofen in the treatment of CUDs was made in a patient affected by CUD and paraplegia who was taking baclofen to treat his spinal cord [134]. This patient reported that when he increased his baclofen dosage from 40 to $80 \mathrm{mg}$ per day (10-20 mg 4 times daily), his craving for cocaine was reduced. A subsequent case report found that baclofen (up to $20 \mathrm{mg}$ t.i.d. for 1 year of treatment) substantially reduced cocaine craving and use in a patient affected by CUD and schizoaffective disorder [135]. In the first open-label study, 10 patients affected by CUDs were treated with baclofen (20 mg t.i.d.), in conjunction with 3 weekly group counseling sessions, for 16 weeks [136]. Cocaine craving and use decreased in these patients. This study provided preliminary data on the safety of baclofen combined with cocaine; 9 patients used cocaine at least once during treatment and did not report lasting or deleterious effects attributable to cocaine/baclofen interaction. Another open study found that the combination of amantadine and baclofen (10 mg t.i.d.) significantly reduced the desire to use cocaine in 8 subjects affected by CUDs, although it did not reduce actual cocaine use [137].

Laboratory Studies. A placebo-controlled crossover trial found that acute, orally administered baclofen $(0,10$, 20 and $30 \mathrm{mg}$ ) did not alter subject-rated and cardiovas- 
cular effects induced by intranasal cocaine in 7 volunteers affected by CUDs who were not seeking treatment [138]. A second laboratory study evaluated the effect of baclofen in 17 volunteers affected by CUDs with and without concurrent opioid dependence [139]. These subjects, admitted to an in-patient research unit for 21 days, received an oral dose of baclofen $(0,30$ and $60 \mathrm{mg})$ for 7 days and underwent a smoked cocaine session or received a voucher. The results showed that baclofen $(60 \mathrm{mg})$ decreased cocaine self-administration in patients without concurrent opioid dependence.

Randomized Studies. A first RCT found that patients assigned to baclofen $(60 \mathrm{mg} /$ day) showed no statistically significant differences compared to the placebo condition although all indices were in the predicted direction [84] (table 3). Post hoc analyses showed statistically significant differences for baclofen compared to placebo in reducing cocaine use, thus suggesting a treatment effect. In this study, 3 patients treated with baclofen developed severe side effects that required overnight hospitalization. A second RCT also found that administration of the same dose of baclofen $(60 \mathrm{mg} /$ day) did not reduce cocaine use in patients affected by CUDs [82] (table 3). Likewise, in the same study, 3 patients developed severe side effects that required hospitalization; however, 2 had been treated with placebo.

\section{Opioid Use Disorders}

Preclinical Studies

Baclofen administration (both systemic and into a specific area of the brain 'reward' system) reduced intravenous heroin self-administration in rats and attenuated the discriminative stimulus effects of morphine [140, $141]$.

\section{Clinical Studies}

A double-blind trial found that the daily oral administration of $60 \mathrm{mg}$ of baclofen nonsignificantly reduced the intensity of opioid craving and self-reported opioid use in patients affected by opioid use disorders [78] (table 3). No patients reported adverse effects that required dose reduction or termination of the treatment.

\section{Opioid Withdrawal Syndrome}

Preclinical Studies

Baclofen administration reduced the intensity of several signs of opioid withdrawal syndrome in rats and mice [142-145].

\section{Clinical Studies}

Open Studies. A pilot study found that the oral administration of baclofen (up to $80 \mathrm{mg} /$ day) was effective in the treatment of opioid withdrawal syndrome in 2 patients out of 5 [146]. In the other 3 patients, baclofen administration was insufficient to suppress vomiting, myalgias and headache.

Randomized Studies. A double-blind clinical trial carried out in Iran showed baclofen to be superior to clonidine in counteracting the physical symptoms of acute opiate withdrawal syndrome, also producing effects earlier than clonidine [76, 77] (table 2). However, baclofen was not superior to placebo in preventing opiate reuse as assessed by urine analysis.

\section{Nicotine Use Disorders}

Preclinical Studies

Treatment with baclofen reduced (1) intravenous nicotine self-administration in rats and mice [147-149]; (2) nicotine-induced CPP in rats and mice $[150,151]$, and (3) nicotine-induced dopamine release in the nucleus accumbens of rats [152]. Finally, acute administration of baclofen attenuated the somatic expression of withdrawal signs in animals made dependent on nicotine [153].

\section{Clinical Studies}

Laboratory Studies. One study found that $20 \mathrm{mg}$ of baclofen administered acutely was able to modify the taste of the cigarette, making it less palatable [154]. Namely, tobacco smokers $(n=16)$ who were not trying to quit received baclofen or placebo (after overnight abstinence) and underwent a session in order to evaluate its effects on cigarette smoking, craving for nicotine, cigarette taste and smoking satisfaction. The results of the study showed that baclofen did not change the number of cigarettes or craving for nicotine. However, it altered the sensory properties of smoked cigarettes (e.g. increasing ratings of 'harsh' and decreasing ratings of 'like cigarette's effects'), indicating a possible important effect of baclofen in smoking abstinence and relapse prevention.

Randomized Studies. One RCT found that baclofen was effective in reducing the number of cigarettes smoked per day compared to placebo, but none of the participants quitted the smoking habit during the study [79] (table 3).

\section{Cannabis Use Disorders}

Preclinical Studies

No preclinical study has been conducted to evaluate baclofen effectiveness in the treatment of cannabis use disorders. 


\section{Clinical Studies}

A case report showed that oral baclofen administration (40 mg t.i.d.) improved symptoms of marijuana withdrawal syndrome and delayed relapse in 6 subjects affected by cannabis use disorders [155]. An open-label study found that baclofen ( 20 or $30 \mathrm{mg}$ t.i.d.) dose-dependently decreased subjective craving for tobacco and marijuana but did not modify marijuana use; nor did it affect relapse into use and worsened cognitive performance [156].

To date, no RCT has been conducted to evaluate baclofen effectiveness in the treatment of cannabis use disorders.

\section{Methamphetamine Use Disorders}

Preclinical Studies

Acute baclofen administration attenuated the development and expression of methamphetamine-induced CPP and decreased intravenous self-administration of amphetamine and methamphetamine in rats [157-159]. Baclofen also attenuated the amphetamine-induced increases in dopamine efflux in the nucleus accumbens [157]. However, baclofen administration has been found to fail to attenuate the discriminative stimulus effects of methamphetamine [133].

\section{Clinical Studies}

The only RCT failed to demonstrate the superiority of $60 \mathrm{mg}$ of baclofen versus placebo on any of the outcome measures evaluated in patients affected by methamphetamine use disorders [81] (table 3). A significant treatment effect was found in post hoc analyses for baclofen relative to placebo among participants who reported taking a higher percentage of study medication.

\section{Inhalant Use Disorders}

Preclinical Studies

No preclinical study has been conducted to evaluate baclofen effectiveness in the treatment of inhalant use disorders.

\section{Clinical Studies}

A case report observed the effectiveness of baclofen (up to $17 \mathrm{mg}$ t.i.d.) in reducing the severity of inhalant withdrawal syndrome in 3 young people who had been abusing inhalants for 2 years or more [160]. Baclofen was well tolerated by these subjects.

\section{Discussion and Conclusions}

A large body of preclinical evidence shows that baclofen administration dose-dependently reduces the intensity of alcohol and heroin withdrawal syndromes as well as voluntary alcohol intake and self-administration of alcohol, cocaine, heroin, nicotine and methamphetamine [161]. However, the number of studies conducted to confirm these results in humans is still low. Globally, 11 RCTs have investigated baclofen effectiveness in the treatment of AUDs $(n=4)$, CUDs $(n=2)$, AWS $(n=1)$, heroin withdrawal syndrome $(n=1)$, NUDs $(n=1)$, opioid use disorders $(\mathrm{n}=1)$ and methamphetamine use disorders $(\mathrm{n}=1)$. Only the number of studies focusing on the treatment of AUDs may be deemed sufficient to provide evidence of baclofen effectiveness in this disorder. However, the results of these 4 RCTs are somewhat divergent; 2 studies found that baclofen is effective, 1 study found that baclofen is ineffective and 1 study did not achieve the preplanned level of participation.

These results prevent the drawing of any conclusions regarding baclofen effectiveness in the treatment of AUDs. However, several reasons may, at least in part, have contributed to the discrepancies in the results obtained. One of them may be ascribed to the use of insufficient doses of baclofen in clinical studies. Preclinical studies have demonstrated that baclofen doses proving effective in reducing alcohol consumption in animal models are more similar to those used in the treatment of spasticity (up to $80 \mathrm{mg} /$ day) than those used in the majority of RCTs (30 mg/day). Namely, preclinical studies have indicated that doses of baclofen effective in decreasing voluntary alcohol intake in alcohol-preferring rats were equal to 5 and $10 \mathrm{mg} / \mathrm{kg}$ when baclofen was administered intraperitoneally [162]. It is not easy to translate doses used in animal models into values to be administered in humans. Usually, small animals require higher doses than humans. It has been evaluated that, when calculated per unit of body weight, 1 dose equivalent for rats corresponds to $1 / 6$ for humans $[163,164]$. In our case, translation also needed to take into account the change in the route of administration, i.e. from parenteral to oral administration, suggesting a further increase in this relationship, perhaps from $1 / 6$ to $1 / 10$. Accordingly, the 2 effective doses used in the above-cited preclinical studies ( 5 and $10 \mathrm{mg} / \mathrm{kg}$ ) would correspond to approximately 37.5 and $75 \mathrm{mg}$ of baclofen for a man of $75 \mathrm{~kg}$ body weight [ $5 \mathrm{mg} / \mathrm{kg} \times 75 \mathrm{~kg}$ body weight $/ 10$ (ratio rats:men) $=37.5$ $\mathrm{mg} ; 10 \mathrm{mg} / \mathrm{kg} \times 75 \mathrm{~kg}$ body weight $/ 10$ (ratio rats:men) $=$ $75 \mathrm{mg}$. This empirical calculation suggests the use of dos- 
es exceeding $30 \mathrm{mg} /$ day. A preclinical study also demonstrated the existence of cross-tolerance between alcohol and baclofen, suggesting that subjects affected by AUDs may require even higher doses of baclofen [92].

Another possible reason underlying the discrepancy in results obtained by preclinical and clinical studies, as well as among clinical studies, may be due to the heterogeneity of patients recruited in the latter. Different typologies of patients display a varying response to medication [165, 166]. Interestingly, a preclinical study found that different lines of alcohol-preferring rats vary in their sensitivity to treatment with baclofen [98]. It has been proposed that one of the main reasons for the divergent results collected by RCTs on AUDs may be the different typologies of patients recruited in these studies [119]. Some of these differences suggest that the Italian studies recruited patients affected by more severe AUDs. The greater efficacy of baclofen in Italian studies might, therefore, be interpreted as baclofen possibly being more potent and effective in individuals affected by severe, rather than only moderate, AUDs. Another important difference among RCTs conducted to evaluate the effectiveness of baclofen was the number of female patients. Further studies should be conducted recruiting higher numbers of women to investigate the relationship between gender and the response to baclofen treatment. Another difference among these RCTs was the number of patients affected by a mental disorder [119]. It has been found that baclofen effectively reduces the severity of anxiety in patients affected by AUDs [13]. Preliminary findings indicate that anxiety may modulate the ability of baclofen to reduce alcohol consumption [118]. Conversely, two recent observational studies found that the coexistence of a mental disorder delayed the response to baclofen treatment $[115,116]$. Several factors may interfere with the response to baclofen in patients affected by AUDs and mental disorders, for example the pharmacological therapy for mental disorders may interact with the ability of baclofen to reduce alcohol consumption. Further studies should be conducted to better characterize patients and to understand the relationship between the types of patients and the different responses to baclofen. In these studies, patients should be investigated to evaluate the possible presence of other mental disorders and the identification of mental disorders as well as their onset, severity and the pharmacological treatment used.

Differences in the response to baclofen treatment may also be due to the different renal function of patients. Baclofen is mainly excreted by the kidneys, and the evaluation of renal function is mandatory prior to administration, as patients with insufficient renal function should

Efficacy and Tolerability of Baclofen in Substance Use Disorders receive lower doses to prevent the onset of side effects. However, it is possible that its administration may indeed have induced better results in patients with low renal function. Accordingly, it has been observed that patients affected by AUDs and cirrhosis require lower doses of baclofen to reduce the craving for alcohol compared to patients affected by AUDs but without cirrhosis [167]. It has been hypothesized that patients affected by cirrhosis may have developed subclinical renal impairment that increases both the therapeutic and side effects of baclofen [167]. Further studies are required to investigate the relationship between renal function and response to baclofen treatment.

Globally, the 5 RCTs conducted to evaluate the response to baclofen treatment of SUDs also reported divergent results; the drug was seen to be effective in the treatment of AWS (1 study out of 1), heroin withdrawal syndrome ( 1 study out of 1 ) and NUDs ( 1 study out of 1 ), whilst it was ineffective in the treatment of CUDs ( 2 studies out of 2), opioid use disorders (1 study out of 1 ) and methamphetamine use disorders (1 study out of 1 ). In this case, the number of studies conducted for each SUD is insufficient to allow any kind of conclusion on baclofen effectiveness to be reached. Likewise, further studies should also be conducted in patients affected by SUDs, to understand the relationship between higher doses, gender, type, renal function, possible presence of other mental disorders and response to baclofen treatment.

Very few studies have compared baclofen effectiveness to that of other drugs currently available for the treatment of AUDs, SUDs or withdrawal syndromes. One study compared the effectiveness of baclofen to that of clonidine in the treatment of heroin withdrawal syndrome [76, 77]. This study found no difference in efficacy between baclofen and clonidine but found that baclofen induced fewer side effects than clonidine (e.g. hypotension and dry mouth). Another study compared the effectiveness of baclofen to that of diazepam in the treatment of AWS, likewise finding no difference in efficacy [126]. Other studies had compared the same two drugs in the treatment of spasticity, finding no difference in efficacy but reporting that baclofen induced less frequent and severe side effects than diazepam $[168,169]$. One of them reported an average duration of baclofen treatment of 4 years with no evidence of drug tolerance [169]. If other studies should confirm its efficacy and safety, the use of baclofen in the treatment of AWS may feature several advantages compared to the use of a benzodiazepine.

The large number of studies undertaken to evaluate the use of baclofen as a muscle relaxant agent and the few 
RCTs conducted to evaluate its effectiveness in the treatment of AUDs, SUDs and withdrawal syndromes have shown that baclofen is devoid of particularly serious side effects when administered under strict medical supervision. To date, baclofen has not displayed addictive properties. Very few cases of abuse for reasons other than attempted suicide have been described among subjects taking this drug as a muscle relaxant agent [38-40]. None of the RCTs in which baclofen was administered to patients affected by AUDs reported the occurrence of craving for baclofen or drug withdrawal symptoms on its discontinuation, whereas the addictive properties of benzodiazepines are well known and constitute a limitation for their use in these patients. Baclofen administration showed a few mild and tolerable side effects also in patients affected by liver cirrhosis [74]. In view of its renal route of excretion, baclofen may be administered to alcohol-dependent patients affected by liver disease that prevents the administration of other drugs metabolized by the liver [170]. However, further studies aimed at evaluating the safety of the drug in patients affected by liver disease should be conducted to avoid any possible risk, such as the onset of acute hepatitis as recently described in a patient affected by AUD after baclofen administration [171].

Baclofen administration to patients affected by AUDs may induce drug interactions caused by the combination of baclofen and alcohol when patients continue to drink. However, a recent laboratory study showed that this combination did not induce particularly severe sedative side effects [117]. Other evidence of the lack of serious consequences of this combination is provided by the large number of individuals affected by multiple sclerosis and AUDs [172, 173] who likely receive oral or intrathecal baclofen and consume alcohol. To our knowledge, no side effects due to this combination among patients affected by multiple sclerosis have been described. An unusual side effect caused by the combination of baclofen and alcohol observed in 4 patients affected by AUDs was the appearance of morbilliform rashes, which resolved completely following reduction of the dose of baclofen [174].

A series of case reports and observational studies indicated that the administration of high doses of baclofen markedly reduced or completely suppressed alcohol intake in patients affected by AUDs $[108-112,115,116]$ as well as the desire to use cocaine in patients affected by CUDs [137]. In France, although baclofen has not been approved for this treatment, an overwhelming number of patients affected by AUDs ask for and receive high doses of baclofen to treat their disorder $[175,176]$. Further studies are required to better understand whether higher doses of baclofen may result in more satisfactory results in the treatment of AUDs and SUDs. This is one of the main aims of the study scheduled for commencement in Amsterdam in the forthcoming months [177]. A possible strategy to potentiate the effects of baclofen may come from the use of PAMs. These compounds possess behavioral activity similar to that of the full $\mathrm{GABA}_{\mathrm{B}}$ receptor agonists, including in tests related to SUDs [97, 178-182]. Preclinical studies have demonstrated that when coadministered with baclofen, PAMs enhance its potency, which could in theory minimize its side effects or imply the use of lower doses of baclofen [183, 184]. However, to date no PAM is available for clinical use.

The results of the present study, similar to the conclusions reached by a recent review on this topic [185], underline the paucity of evidence required to suggest baclofen administration as a first-line pharmacological option for use in the treatment of patients affected by AUDs as well as SUDs. The use of other drugs with more satisfactory evidence should be attempted in these patients prior to baclofen. Moreover, it should be underlined that the majority of patients receive no pharmacological treatment for AUDs, and when drug treatment is prescribed, this is frequently not the most effective [186].

Baclofen administration may be suggested in patients affected by AUDs or SUDs who fail to respond to other approved drugs or who are affected by liver disease that prevents the administration of drugs metabolized by the liver. It may also be suggested in patients affected by SUDs for which no approved drugs are available. Renal function should be carefully assessed prior to baclofen administration. An initial dose of $5 \mathrm{mg} 3$ times a day should be employed, and the response to baclofen treatment should be evaluated on the basis of craving for alcohol or other substances. When needed, and if possible, after 3 days of administration of the drug, the dose may be increased by an additional $5 \mathrm{mg}, 3$ times daily, to achieve the optimum effective dose for treatment of craving. Treatment should be conducted under strict medical supervision, and patients should be advised against self-administration and/ or abrupt discontinuation of baclofen.

In conclusion, preclinical studies suggest that baclofen may constitute a useful pharmacological agent for the treatment of withdrawal syndromes and SUDs. However, the number of studies conducted to confirm these results in humans is still low, and their results are divergent. In an attempt to explain this discrepancy, the administration of insufficient doses of baclofen would appear to represent one of the most important causes. Further studies 
should therefore be performed to evaluate the effectiveness of higher doses of baclofen - closer to those suggested for the treatment of spasticity and those suggested by preclinical studies - in the treatment of AUDs as well as SUDs.

\section{Acknowledgments}

The authors are grateful to Drs. Giovanni Addolorato and Lorenzo Leggio for providing details of their studies and Mrs. Anne Farmer for language editing of the manuscript.

\section{References}

1 Mark TL, Kassed CA, Vandivort-Warren R, Levit KR, Kranzler HR: Alcohol and opioid dependence medications: prescription trends, overall and by physician specialty. Drug Alcohol Depend 2009;99:345-349.

-2 Grant BF: Barriers to alcoholism treatment: reasons for not seeking treatment in a general population sample. J Stud Alcohol 1997;58: 365-371.

-3 Schomerus G, Lucht M, Holzinger A, Matschinger $\mathrm{H}$, Carta MG, Angermeyer MC: The stigma of alcohol dependence compared with other mental disorders: a review of population studies. Alcohol Alcohol 2011;46:105112.

-4 Miller NS, Sheppard LM, Colenda CC, Magen $\mathrm{J}$ : Why physicians are unprepared to treat patients who have alcohol- and drug-related disorders. Acad Med 2001;76:410-418.

5 Jupp B, Lawrence AJ: New horizons for therapeutics in drug and alcohol abuse. Pharmacol Ther 2010;125:138-168.

-6 Tyacke RJ, Lingford-Hughes A, Reed LJ, Nutt DJ: GABAB receptors in addiction and its treatment. Adv Pharmacol 2010;58:373-396.

7 Bowery NG: $\mathrm{GABA}_{\mathrm{B}}$ receptor: a site of therapeutic benefit. Curr Opin Pharmacol 2006;6: 37-43.

$>8$ Dario A, Tomei G: A benefit-risk assessment of baclofen in severe spinal spasticity. Drug Saf 2004;27:799-818.

$>9$ Abbruzzese G: The medical management of spasticity. Eur J Neurol 2002;9:30-34.

$\checkmark 10$ Cryan JF, Kaupmann K: Don't worry 'B' happy!: a role for $\mathrm{GABA}(\mathrm{B})$ receptors in anxiety and depression. Trends Pharmacol Sci 2005; 26:36-43.

11 Breslow MF, Fankhauser MP, Potter RL, Meredith KE, Misiaszek J, Hope DG Jr: Role of gamma-aminobutyric acid in antipanic drug efficacy. Am J Psychiatry 1989;146:353-356.

- 12 Drake RG, Davis LL, Cates ME, Jewell ME, Ambrose SM, Lowe JS: Baclofen treatment for chronic posttraumatic stress disorder. Ann Pharmacother 2003;37:1177-1181

$\checkmark 13$ Krupitsky EM, Burakov AM, Ivanov VB, Krandashova GF, Lapin IP, Grinenko AJ, Borodkin YS: Baclofen administration for the treatment of affective disorders in alcoholic patients. Drug Alcohol Depend 1993;33:157_ 163.

14 Broft AI, Spanos A, Corwin RL, Mayer L, Steinglass J, Devlin MJ, Attia E, Walsh BT: Baclofen for binge eating: an open-label trial. Int J Eat Disord 2007;40:687-691.
15 Bigelow LB, Nasrallah H, Carman J, Gillin JC, Wyatt RJ: Baclofen treatment in chronic schizophrenia: a clinical trial. Am J Psychiatry 1977;134:318-320.

16 Gulmann NC, Bahr B, Andersen B, Eliassen HM: A double-blind trial of baclofen against placebo in the treatment of schizophrenia. Acta Psychiatr Scand 1976;54:287-293.

17 Hering-Hanit R, Gadoth N: The use of baclofen in cluster headache. Curr Pain Headache Rep 2001;5:79-82.

18 Cossentino MJ, Mann K, Armbruster SP, Lake JM, Maydonovitch C, Wong RK: Randomised clinical trial: the effect of baclofen in patients with gastro-oesophageal reflux - a randomised prospective study. Aliment Pharmacol Ther 2012, E-pub ahead of print.

19 Orr WC, Goodrich S, Wright S, Shepherd K, Mellow M: The effect of baclofen on nocturnal gastroesophageal reflux and measures of sleep quality: a randomized, cross-over trial. Neurogastroenterol Motil 2012;24:553-e253.

20 Burke AM, White AB, Brill N: Baclofen for intractable hiccups. N Engl J Med 1988;319: 1354.

21 Froestl W: Chemistry and pharmacology of GABAB receptor ligands. Adv Pharmacol 2010;58:19-62.

22 Emson PC: GABAB receptors: structure and function; in Tepper JM, Abercrombie ED, Bolam JP (eds): Progress in Brain Research. Amsterdam, Elsevier, 2007, pp 43-57.

23 Lal R, Sukbuntherng J, Tai EH, Upadhyay S, Yao F, Warren MS, Luo W, Bu L, Nguyen S, Zamora J, Peng G, Dias T, Bao Y, Ludwikow M, Phan T, Scheuerman RA, Yan H, Gao M, Wu QQ, Annamalai T, Raillard SP, Koller K, Gallop MA, Cundy KC: Arbaclofen placarbil, a novel R-baclofen prodrug: improved ab sorption, distribution, metabolism, and elimination properties compared with R-baclofen J Pharmacol Exp Ther 2009;330:911-921.

24 Urwyler S, Mosbacher J, Lingenhoehl K, Heid J, Hofstetter K, Froestl W, Bettler B, Kaupmann K: Positive allosteric modulation of native and recombinant gamma-aminobutyric acid(B) receptors by 2,6-Di-tert-butyl-4-(3-hydroxy-2,2-dimethyl-propyl)-phenol (CGP7930) and its aldehyde analog CGP13501. Mol Pharmacol 2001;60:963-971.

25 Urwyler S, Pozza MF, Lingenhoehl K, Mosbacher J, Lampert C, Froestl W, Koller M, Kaupmann K: N,N'-Dicyclopentyl-2-methylsulfanyl-5-nitro-pyrimidine-4,6-diamine (GS39783) and structurally related com- pounds: novel allosteric enhancers of gammaaminobutyric acidB receptor function. J Pharmacol Exp Ther 2003;307:322-330.

26 Urwyler S: Allosteric modulation of family C G-protein-coupled receptors: from molecular insights to therapeutic perspectives. Pharmacol Rev 2011;63:59-126.

27 Koob GF, Volkow ND: Neurocircuitry of addiction. Neuropsychopharmacology 2010;35: 217-238.

28 Chen G, Cuzon Carlson VC, Wang J, Beck A, Heinz A, Ron D, Lovinger DM, Buck KJ: Striatal involvement in human alcoholism and alcohol consumption, and withdrawal in animal models. Alcohol Clin Exp Res 2011;35: 1739-1748

29 Colombo G, Agabio R, Carai MAM, Lobina C, Pani M, Reali R, Addolorato G, Gessa GL: Ability of baclofen in reducing alcohol intake and withdrawal severity. I. Preclinical evidence. Alcohol Clin Exp Res 2000;24:58-66.

30 Gerkin R, Curry SC, Vance MV, Sankowski PW, Meinhart RD: First-order elimination kinetics following baclofen overdose. Ann Emerg Med 1986;15:843-846.

31 Wuis EW, Dirks MJ, Termond EF, Vree TB, Van der Kleijn E: Plasma and urinary excretion kinetics of oral baclofen in healthy subjects. Eur J Clin Pharmacol 1989;37:181-184.

32 Smith CR, LaRocca NG, Giesser BS, Scheinberg LC: High-dose oral baclofen: experience in patients with multiple sclerosis. Neurology 1991;41:1829-1831.

33 Chen KS, Bullard MJ, Chien YY, Lee SY: Baclofen toxicity in patients with severely impaired renal function. Ann Pharmacother 1997;31:1315-1320.

34 El-Husseini A, Sabucedo A, Lamarche J, Courville C, Peguero A: Baclofen toxicity in patients with advanced nephropathy: proposal for new labeling. Am J Nephrol 2011;34: 491-495.

35 Ghose K, Holmes KM, Matthewson K: Complications of baclofen overdosage. Postgrad Med J 1980;56:865-867.

36 Ochs G, Struppler A, Meyerson BA, Linderoth $\mathrm{B}$, Gybels J, Gardner BP, Teddy P, Jamous A, Weinmann P: Intrathecal baclofen for long-term treatment of spasticity: a multicentre study. J Neurol Neurosurg Psychiatry 1989;52:933-939.

37 Awaad Y, Rizk T, Siddiqui I, Roosen N, McIntosh K, Waines GM: Complications of intrathecal baclofen pump: prevention and cure. ISRN Neurol 2012;2012:575168.
Efficacy and Tolerability of Baclofen in Substance Use Disorders
Eur Addict Res 2013:19:325-345 
38 Nasti JJ, Brakoulias V: Chronic baclofen 55 Leo RJ, Baer D: Delirium associated with abuse and withdrawal delirium. Aust NZ J Psychiatry 2011;45:86-87.

39 Perry HE, Wright RO, Shannon MW, Woolf AD: Baclofen overdose: drug experimentation in a group of adolescents. Pediatrics 1998;101:1045-1048.

40 Weißhaar GF, Hoemberg M, Bender K, Bangen U, Herkenrath P, Eifinger F, Rothschild M, Roth B, Oberthuer A: Baclofen intoxication: a 'fun drug' causing deep coma and nonconvulsive status epilepticus - a case report and review of the literature. Eur J Pediatr 2012;171:1541-1547.

-41 Lee TH, Chen SS, Su SL, Yang SS: Baclofen intoxication: report of four cases and review of the literature. Clin Neuropharmacol 1992; 15:56-62.

-42 Berger B, Vienenkoetter B, Korporal M, Rocco A, Meinck HM, Steiner T: Accidental intoxication with $60 \mathrm{mg}$ intrathecal baclofen survived. Neurocrit Care 2012;16:428-432.

-43 Ferner RE: Atropine treatment for baclofen overdose. Postgrad Med J 1981;57:580-581.

44 Hsieh MJ, Chen SC, Weng TI, Fang CC, Tsai TJ: Treating baclofen overdose by hemodialysis. Am J Emerg Med 2012;30:1654.e5-1654. e7.

45 Lipscomb DJ, Meredith TJ: Baclofen overdose. Postgrad Med J 1980;56:108-109.

-46 Romijn JA, van Lieshout JJ, Velis DN: Reversible coma due to intrathecal baclofen. Lancet 1986;ii:696.

-47 Saltuari L, Baumgartner H, Kofler M, Schmutzhard E, Russegger L, Aichner F, Gerstenbrand F: Failure of physostigmine in treatment of acute severe intrathecal baclofen intoxication. N Engl J Med 1990;322:1533-1534.

-48 Sauneuf B, Totouom HK, Savary B, Varin L, Dupeyrat J, Ramakers S, Hanouz JL: Clinical and EEG features of acute intrathecal baclofen overdose. Clin Neurol Neurosurg 2012; 114:84-86.

-49 Sullivan R, Hodgman MJ, Kao L, Tormoehlen LM: Baclofen overdose mimicking brain death. Clin Toxicol (Phila) 2012;50:141-144.

50 Wall GC, Wasiak A, Hicklin GA: An initially unsuspected case of baclofen overdose. Am J Crit Care 2006;15:611-613.

-51 Chong CF, Wang TL: An unusual presentation of baclofen overdose. Emerg Med J 2005 22:673-674.

52 Saissy JM, Vitris M, Demazière J, Seck M, Marcoux L, Gaye M: Flumazenil counteracts intrathecal baclofen-induced central nervous system depression in tetanus. Anesthesiology 1992;76:1051-1053.

53 Dias LS, Vivek G, Manthappa M, Acharya RV: Role of hemodialysis in baclofen overdose with normal renal function. Indian J Pharmacol 2011;43:722-723.

-54 Wu VC, Lin SL, Lin SM, Fang CC: Treatment of baclofen overdose by haemodialysis: a pharmacokinetic study. Nephrol Dial Transplant 2005;20:441-443. baclofen withdrawal: a review of common presentations and management strategies. Psychosomatics 2005;46:503-507.

56 Barker I, Grant IS: Convulsions after abrupt withdrawal of baclofen. Lancet 1982;ii:556557.

57 Greenberg MI, Hendrickson RG: Baclofen withdrawal following removal of an intrathecal baclofen pump despite oral baclofen replacement. J Toxicol Clin Toxicol 2003;41: 83-85.

58 Karol DE, Muzyk AJ, Preud'homme XA: A case of delirium, motor disturbances, and autonomic dysfunction due to baclofen and tizanidine withdrawal: a review of the literature. Gen Hosp Psychiatry 2011;33:84.e1-84.e2.

59 Malhotra T, Rosenzweig I: Baclofen withdrawal causes psychosis in otherwise unclouded consciousness. J Neuropsychiatry Clin Neurosci 2009;21:476.

60 Ratnayaka BD, Dhaliwal H, Watkin S: Drug points: neonatal convulsions after withdrawal of baclofen. BMJ 2001;323:85.

61 Ross JC, Cook AM, Stewart GL, Fahy BG: Acute intrathecal baclofen withdrawal: a brief review of treatment options. Neurocrit Care 2011;14:103-108.

62 Specchio N, Carotenuto A, Trivisano M, Cappelletti S, Vigevano F, Fusco L: Prolonged episode of dystonia and dyskinesia resembling status epilepticus following acute intrathecal baclofen withdrawal. Epilepsy Behav 2011;21: 321-323.

63 Terrence CF, Fromm GH: Complications of baclofen withdrawal. Arch Neurol 1981;38: 588-589.

64 Green LB, Nelson VS: Death after acute withdrawal of intrathecal baclofen: case report and literature review. Arch Phys Med Rehabil 1999;80:1600-1604.

65 Meinck HM, Tronnier V, Rieke K, Wirtz CR, Flügel D, Schwab S: Intrathecal baclofen treatment for stiff-man syndrome: pump failure may be fatal. Neurology 1994;44:2209-2210.

66 Kleber HD, Weiss RD, Anton RF Jr, George TP, Greenfield SF, Kosten TR, O’Brien CP, Rounsaville BJ, Strain EC, Ziedonis DM, Hennessy G, Connery HS, McIntyre JS, Charles SC, Anzia DJ, Cook IA, Finnerty MT, Johnson BR, Nininger JE, Summergrad P, Woods SM, Yager J, Pyles R, Cross CD, Peele R, Shemo JP, Lurie L, Walker RD, Barnovitz MA, Gray SH, Saxena S, Tonnu T, Kunkle R, Albert AB, Fochtmann LJ, Hart C, Regier D; Work Group on Substance Use Disorders; American Psychiatric Association; Steering Committee on Practice Guidelines: Treatment of patients with substance use disorders, second edition. American Psychiatric Association. Am J Psychiatry 2007;164(4 suppl):5-123.

67 Higgins JP, Altman DG, Gøtzsche PC, Jüni P, Moher D, Oxman AD, Savovic J, Schulz KF, Weeks L, Sterne JA; Cochrane Bias Methods Group; Cochrane Statistical Methods Group: The Cochrane Collaboration's tool for assessing risk of bias in randomised trials. BMJ 2011;343:d5928.
68 Higgins JP, Thompson SG, Deeks JJ, Altman DG: Measuring inconsistency in meta-analyses. BMJ 2003;327:557-560.

-69 Egger M, Davey Smith G, Schneider M, Minder C: Bias in meta-analysis detected by a simple, graphical test. BMJ 1997;315:629-634.

$>70$ Duval S, Tweedie R: A nonparametric 'trim and fill' method of accounting for publication bias in meta-analysis. J Am Stat Assoc 2000; 95:89-98.

71 DerSimonian R, Laird N: Meta-analysis in clinical trials. Control Clin Trials 1986;7:177188.

72 Rosenthal R: The 'file drawer problem' and tolerance for null results. Psychol Bull 1979; 86:638-641.

73 Addolorato G, Caputo F, Capristo E, Domenicali M, Bernardi M, Janiri L, Agabio R, Colombo G, Gessa GL, Gasbarrini G: Baclofen efficacy in reducing alcohol craving and intake: a preliminary double-blind randomized controlled study. Alcohol Alcohol 2002;37: 504-508.

74 Addolorato G, Leggio L, Ferrulli A, Cardone S, Vonghia L, Mirijello A, Abenavoli L, D’Angelo C, Caputo F, Zambon A, Haber PS, Gasbarrini G: Effectiveness and safety of baclofen for maintenance of alcohol abstinence in alcohol-dependent patients with liver cirrhosis: randomised, double-blind controlled study. Lancet 2007;370:1915-1922.

75 Addolorato G, Leggio L, Ferrulli A, Cardone S, Bedogni G, Caputo F, Gasbarrini G, Landolfi R: Dose-response effect of baclofen in reducing daily alcohol intake in alcohol dependence: secondary analysis of a randomized, double-blind, placebo-controlled trial. Alcohol Alcohol 2011;46:312-317.

76 Ahmadi-Abhari SA, Akhondzadeh S, Assadi SM, Shabestari OL, Farzanehgan ZM, Kamlipour A: Baclofen versus clonidine in the treatment of opiates withdrawal, side-effects aspect: a double-blind randomized controlled trial. J Clin Pharm Ther 2001;26:67-71.

77 Akhondzadeh S, Ahmadi-Abhari SA, Assadi SM, Shabestari OL, Kashani AR, Farzanehgan ZM: Double-blind randomized controlled trial of baclofen vs. clonidine in the treatment of opiates withdrawal. J Clin Pharm Ther 2000; 25:347-353.

78 Assadi SM, Radgoodarzi R, Ahmadi-Abhari SA: Baclofen for maintenance treatment of opioid dependence: a randomized doubleblind placebo-controlled clinical trial [ISRCTN32121581]. BMC Psychiatry 2003;3:16.

79 Franklin TR, Harper D, Kampman K, KildeaMcCrea S, Jens W, Lynch KG, O’Brien CP, Childress AR: The GABA B agonist baclofen reduces cigarette consumption in a preliminary double-blind placebo-controlled smoking reduction study. Drug Alcohol Depend 2009;103:30-36.

80 Garbutt JC, Kampov-Polevoy AB, Gallop R, Kalka-Juhl L, Flannery BA: Efficacy and safety of baclofen for alcohol dependence: a randomized, double-blind, placebo-controlled trial. Alcohol Clin Exp Res 2010;34:1849-1857. 
81 Heinzerling KG, Shoptaw S, Peck JA, Yang X, Liu J, Roll J, Ling W: Randomized, placebocontrolled trial of baclofen and gabapentin for the treatment of methamphetamine dependence. Drug Alcohol Depend 2006;85:177184.

82 Kahn R, Biswas K, Childress AR, Shoptaw S, Fudala PJ, Gorgon L, Montoya I, Collins J, McSherry F, Li SH, Chiang N, Alathari H, Watson D, Liberto J, Beresford T, Stock C, Wallace C, Gruber V, Elkashef A: Multi-center trial of baclofen for abstinence initiation in severe cocaine-dependent individuals. Drug Alcohol Depend 2009;103:59-64.

83 Lyon JE, Khan RA, Gessert CE, Larson PM, Renier CM: Treating alcohol withdrawal with oral baclofen: a randomized, double-blind, placebo-controlled trial. J Hosp Med 2011;6: 474-479.

-84 Shoptaw S, Yang X, Rotheram-Fuller EJ, Hsieh YC, Kintaudi PC, Charuvastra VC, Ling W: Randomized placebo-controlled trial of baclofen for cocaine dependence: preliminary effects for individuals with chronic patterns of cocaine use. J Clin Psychiatry 2003; 64:1440-1448.

-85 Daoust M, Saligaut C, Lhuintre JP, Moore N, Flipo JL, Boismare F: GABA transmission, but not benzodiazepine receptor stimulation, modulates ethanol intake by rats. Alcohol 1987;4:469-472.

-86 Quintanilla ME, Perez E, Tampier L: Baclofen reduces ethanol intake in high-alcohol-drinking University of Chile bibulous rats. Addict Biol 2008; 13:326-336.

87 Smith BR, Boyle AEL, Amit Z: The effects of $\mathrm{GABA}_{\mathrm{B}}$ agonist baclofen on the temporal and structural characteristics of ethanol intake. Alcohol 1999;17:231-240.

88 Stromberg MF: The effect of baclofen alone and in combination with naltrexone on ethanol consumption in the rat. Pharmacol Biochem Behav 2004;78:743-750.

-89 Colombo G, Serra S, Brunetti G, Vacca G, Carai MAM, Gessa GL: Suppression by baclofen of alcohol deprivation effect in Sardinian alcohol-preferring (sP) rats. Drug Alcohol Depend 2003;70:105-108.

90 Colombo G, Serra S, Vacca G, Carai MAM, Gessa GL: Baclofen-induced suppression of alcohol deprivation effect in Sardinian alcohol-preferring $(\mathrm{sP})$ rats exposed to different alcohol concentrations. Eur J Pharmacol 2006;550:123-126.

-91 Anstrom KK, Cromwell HC, Markowski T, Woodward DJ: Effect of baclofen on alcohol and sucrose self-administration in rats. Alcohol Clin Exp Res 2003;27:900-908.

-92 Besheer J, Lepoutre V, Hodge CW: GABA receptor agonists reduce operant ethanol selfadministration and enhance ethanol sedation in C57BL/6J mice. Psychopharmacology (Berl) 2004;174:358-366

93 Duke AN, Kaminski BJ, Weerts EM: Baclofen effects on alcohol seeking, self-administration and extinction of seeking responses in a within-session design in baboons. Addict Biol 2012, E-pub ahead of print.
94 Janak PH, Gill TM: Comparison of the effects of allopregnanolone with direct GABAergic agonists on ethanol self-administration with and without concurrently available sucrose. Alcohol 2003;30:1-7.

95 Liang JH, Chen F, Krstew E, Cowen MS, Carroll FY, Crawford D, Beart PM, Lawrence AJ: The $\mathrm{GABA}_{\mathrm{B}}$ receptor allosteric modulator CGP7930, like baclofen, reduces operant selfadministration of ethanol in alcohol-preferring rats. Neuropharmacology 2006;50:632639.

-96 Maccioni P, Serra S, Vacca G, Orrù A, Pes D, Agabio R, Addolorato G, Carai MA, Gessa GL, Colombo G: Baclofen-induced reduction of alcohol reinforcement in alcoholpreferring rats. Alcohol 2005;36:161-168.

$\$ 97$ Maccioni P, Colombo G: Role of the GABA(B) receptor in alcohol seeking and drinking behavior. Alcohol 2009;43:555558.

$\$ 98$ Maccioni P, Zaru A, Loi B, Lobina C, Carai MAM, Gessa GL, Capra A, Mugnaini C, Pasquini S, Corelli F, Hyytiä P, Lumeng L, Colombo G: Comparison of the effect of the $\mathrm{GABA}_{\mathrm{B}}$ receptor agonist, baclofen, and the positive allosteric modulator of the $\mathrm{GABA}_{\mathrm{B}}$ receptor, GS39783, on alcohol self-administration in three different lines of alcohol-preferring rats. Alcohol Clin Exp Res 2012;36:1748-1766.

$\$ 99$ Walker BM, Koob GF: The $\gamma$-aminobutyric acid-B receptor agonist baclofen attenuates responding for ethanol in ethanol-dependent rats. Alcohol Clin Exp Res 2007;31:11-18.

100 Maccioni P, Bienkowski P, Carai MA, Gessa GL, Colombo G: Baclofen attenuates cue-induced reinstatement of alcohol-seeking behavior in Sardinian alcohol-preferring (sP) rats. Drug Alcohol Depend 2008;95:284-287.

101 Bechtholt AJ, Cunningham CL: Ethanol-induced conditioned place preference is expressed through a ventral tegmental area dependent mechanism. Behav Neurosci 2005; 119:213-223.

102 Arias C, Mlewski EC, Molina JC, Spear NE: Naloxone and baclofen attenuate ethanol's locomotor-activating effects in preweanling Sprague-Dawley rats. Behav Neurosci 2009; 123:172-180.

103 Boehm SL 2nd, Piercy MM, Bergstrom HC, Phillips TJ: Ventral tegmental area region governs $\mathrm{GABA}_{\mathrm{B}}$ receptor modulation of ethanol-stimulated activity in mice. Neuroscience 2002;115:185-200.

104 Chester JA, Cunningham CL: Baclofen alters ethanol-stimulated activity but not conditioned place preference or taste aversion in mice. Pharmacol Biochem Behav 1999;63: 325-331.

105 Holstein SE, Dobbs L, Phillips TJ: Attenuation of the stimulant response to ethanol is associated with enhanced ataxia for a $\mathrm{GABA}_{\mathrm{A}}$, but not a $\mathrm{GABA}_{\mathrm{B}}$, receptor agonist. Alcohol Clin Exp Res 2009;33:108-120.

106 Petry NM: Benzodiazepine-GABA modulation of concurrent ethanol and sucrose reinforcement in the rat. Exp Clin Psychopharmacol 1997;5:183-194.
07 Czachowski CL, Legg BH, Stansfield KH: Ethanol and sucrose seeking and consumption following repeated administration of the GABA(B) agonist baclofen in rats. Alcohol Clin Exp Res 2006;30:812-818.

08 Ameisen O: Complete and prolonged suppression of symptoms and consequences of alcohol-dependence using high-dose baclofen: a self-case report of a physician. Alcohol Alcohol 2005;40:147-150.

109 Bucknam W: Suppression of symptoms of alcohol dependence and craving using highdose baclofen. Alcohol Alcohol 2007;42: 158-160.

110 Pastor A, Jones DM, Currie J: High-dose baclofen for treatment-resistant alcohol dependence. J Clin Psychopharmacol 2012;32: 266-268.

111 Agabio R, Marras P, Addolorato G, Carpiniello B, Gessa GL: Baclofen suppresses alcohol intake and craving for alcohol in a schizophrenic alcohol-dependent patient: a case report. J Clin Psychopharmacol 2007;27:319320.

112 Dore GM, Lo K, Juckes L, Bezyan S, Latt N: Clinical experience with baclofen in the management of alcohol-dependent patients with psychiatric comorbidity: a selected case series. Alcohol Alcohol 2011;46:714-720.

113 Addolorato G, Caputo F, Capristo E, Colombo G, Gessa GL, Gasbarrini G: Ability of baclofen in reducing alcohol craving and intake. II. Preliminary clinical evidence. Alcohol Clin Exp Res 2000;24:67-71.

114 Flannery BA, Garbutt JC, Cody MW, Renn W, Grace K, Osborne M, Crosby K, Morreale $\mathrm{M}$, Trivette A: Baclofen for alcohol dependence: a preliminary open-label study. Alcohol Clin Exp Res 2004;28:1517-1523.

115 Rigal L, Alexandre-Dubroeucq C, de Beaurepaire $\mathrm{R}$, Le Jeunne $\mathrm{C}$, Jaury P: Abstinence and 'low-risk' consumption 1 year after the initiation of high-dose baclofen: a retrospective study among 'high-risk' drinkers. Alcohol Alcohol 2012;47:439-442.

116 de Beaurepaire R: Suppression of alcohol dependence using baclofen: a 2-year observational study of 100 patients. Front Psychiatry 2012;3:103.

117 Evans SM, Bisaga A: Acute interaction of baclofen in combination with alcohol in heavy social drinkers. Alcohol Clin Exp Res 2009;33:19-30.

118 Leggio L, Zywiak WH, McGeary JE, Edwards S, Fricchione SR, Shoaff JR, Addolorato G, Swift RM, Kenna GA: A human laboratory pilot study with baclofen in alcoholic individuals. Pharmacol Biochem Behav 2013;103:784-791.

119 Leggio L, Garbutt JC, Addolorato G: Effectiveness and safety of baclofen in the treatment of alcohol dependent patients. CNS Neurol Disord Drug Targets 2010;9:33-44.

120 File SE, Zharkovsky A, Gulati K: Effects of baclofen and nitrendipine on ethanol withdrawal responses in the rat. Neuropharmacology 1991;30:183-190.
Efficacy and Tolerability of Baclofen in Substance Use Disorders
Eur Addict Res 2013;19:325-345 
-121 Knapp DJ, Overstreet DH, Breese GR: Baclofen blocks expression and sensitization of anxiety-like behavior in an animal model of repeated stress and ethanol withdrawal. Alcohol Clin Exp Res 2007;31:582-595.

122 Humeniuk RE, White JM, Ong J: The effects of GABAB ligands on alcohol withdrawal in mice. Pharmacol Biochem Behav 1994;49: 561-566.

-123 Addolorato G, Caputo F, Capristo E, Janiri L, Bernardi M, Agabio R, Colombo G, Gessa GL, Gasbarrini G: Rapid suppression of alcohol withdrawal syndrome by baclofen. Am J Med 2002;112:226-229.

-124 Addolorato G, Leggio L, Abenavoli L, DeLorenzi G, Parente A, Caputo F, Janiri L, Capristo E, Rapaccini GL, Gasbarrini G: Suppression of alcohol delirium tremens by baclofen administration: a case report. Clin Neuropharmacol 2003;26:258-262.

-125 Stallings W, Schrader S: Baclofen as prophylaxis and treatment for alcohol withdrawal: a retrospective chart review. J Okla State Med Assoc 2007;100:354-360.

- 126 Addolorato G, Leggio L, Abenavoli L, Agabio R, Caputo F, Capristo E, Colombo G, Gessa GL, Gasbarrini G: Baclofen in the treatment of alcohol withdrawal syndrome: a comparative study vs. diazepam. Am J Med 2006;119:276.e13-276.e18.

127 Liu J, Wang L: Baclofen for alcohol withdrawal. Cochrane Database Syst Rev 2011; 19:CD008502.

128 Brebner K, Phelan R, Roberts DC: Effect of baclofen on cocaine self-administration in rats reinforced under fixed-ratio 1 and progressive-ratio schedules. Psychopharmacology (Berl) 2000;148:314-321.

-129 Campbell UC, Lac ST, Carroll ME: Effects of baclofen on maintenance and reinstatement of intravenous cocaine self-administration in rats. Psychopharmacology (Berl) 1999; 143:209-214.

130 Roberts DCS, Andrews MM, Vickers GJ: Baclofen attenuates the reinforcing effects of cocaine in rats. Neuropsychopharmacology 1996;15:417-423.

131 Roberts DCS, Andrews MM: Baclofen suppression of cocaine self-administration: demonstration using a discrete trials procedure. Psychopharmacology (Berl) 1997;131: 271-277.

132 Shoaib M, Swanner LS, Beyer CE, Goldberg SR, Schindler CW: The GABAB agonist baclofen modifies cocaine self-administration in rats. Behav Pharmacol 1998;9:195-206.

-133 Munzar P, Kutkat SW, Miller CR, Goldberg SR: Failure of baclofen to modulate discriminative-stimulus effects of cocaine or methamphetamine in rats. Eur J Pharmacol 2000; 408:169-174.

$\checkmark 134$ Brebner K, Childress AR, Roberts DC: A potential role for $\operatorname{GABA}(\mathrm{B})$ agonists in the treatment of psychostimulant addiction. Alcohol Alcohol 2002;37:478-484.

-135 Kaplan GB, McRoberts RL 3rd, Smokler HJ: Baclofen as adjunctive treatment for a patient with cocaine dependence and schizoaf- fective disorder. J Clin Psychopharmacol 2004;24:574-575.

136 Ling W, Shoptaw S, Majewska D: Baclofen as a cocaine anti-craving medication: a preliminary clinical study. Neuropsychopharmacology 1998;18:403-404.

137 Rotheram-Fuller E, De La Garza R 2nd, Mahoney JJ 3rd, Shoptaw S, Newton TF: Subjective and cardiovascular effects of cocaine during treatment with amantadine and baclofen in combination. Psychiatry Res 2007;152:205-210.

138 Lile JA, Stoops WW, Allen TS, Glaser PE, Hays LR, Rush CR: Baclofen does not alter the reinforcing, subject-rated or cardiovascular effects of intranasal cocaine in humans. Psychopharmacology (Berl) 2004;171:441-449.

139 Haney M, Hart CL, Foltin RW: Effects of baclofen on cocaine self-administration: opioidand nonopioid-dependent volunteers. Neuropsychopharmacology 2006;31:1814-1821.

140 Bartoletti M, Colantoni A, De Luca V, Gaiardi M: Single and repeated baclofen treatment attenuates the discriminative stimulus effects of morphine in rats. Pharmacol Biochem Behav 2010;97:279-283.

141 Xi ZX, Stein EA: Baclofen inhibits heroin self-administration behavior and mesolimbic dopamine release. J Pharmacol Exp Ther 1999;290:1369-1374.

142 Bexis S, Ong J, White J: Attenuation of morphine withdrawal signs by the $\mathrm{GABA}(\mathrm{B})$ receptor agonist baclofen. Life Sci 2001;70: 395-401.

143 Diaz SL, Kemmling AK, Rubio MC, Balerio GN: Lack of sex-related differences in the prevention by baclofen of the morphine withdrawal syndrome in mice. Behav Pharmacol 2001;12:75-79.

144 Kemmling AK, Rubio MC, Balerio GN: Baclofen prevents morphine withdrawal irrespective of seasonal variation. Behav Pharmacol 2002;13:87-92.

145 Zarrindast MR, Mousa-Ahmadi E: Effects of GABAergic system on naloxone-induced jumping in morphine-dependent mice. Eur J Pharmacol 1999;381:129-133.

146 Krystal JH, McDougle CJ, Kosten TR, Price LH, Aghajanian GK, Charney DS: Baclofenassisted detoxification from opiates. A pilot study. J Subst Abuse Treat 1992;9:139-142.

147 Corrigall WA, Coen KM, Adamson KL, Chow BL, Zhang J: Response of nicotine selfadministration in the rat to manipulations of mu-opioid and gamma-aminobutyric acid receptors in the ventral tegmental area. Psychopharmacology (Berl) 2000;149:107-114 .

148 Fattore L, Cossu G, Martellotta MC, Fratta $\mathrm{W}$ : Baclofen antagonizes intravenous selfadministration of nicotine in mice and rats. Alcohol Alcohol 2002;37:495-498.

149 Paterson NE, Froestl W, Markou A: The GABAB receptor agonists baclofen and CGP44532 decreased nicotine self-administration in the rat. Psychopharmacology (Berl) 2004;172:179-186.

150 Le Foll B, Wertheim CE, Goldberg SR: Effects of baclofen on conditioned rewarding and discriminative stimulus effects of nicotine in rats. Neurosci Lett 2008;443:236-240.

151 Fattore L, Spano MS, Cossu G, Scherma M, Fratta W, Fadda P: Baclofen prevents druginduced reinstatement of extinguished nicotine-seeking behaviour and nicotine place preference in rodents. Eur Neuropsychopharmacol 2009;19:487-498.

152 Fadda P, Scherma M, Fresu A, Collu M, Fratta W: Baclofen antagonizes nicotine-, cocaine-, and morphine-induced dopamine release in the nucleus accumbens of rat. Synapse 2003;50:1-6.

153 Varani AP, Moutinho LM, Calvo M, Balerio GN: Ability of baclofen to prevent somatic manifestations and neurochemical changes during nicotine withdrawal. Drug Alcohol Depend 2011;119:e5-e12.

154 Cousins MS, Stamat HM, de Wit H: Effects of a single dose of baclofen on self-reported subjective effects and tobacco smoking. Nicotine Tob Res 2001;3:123-129.

155 Nanjayya SB, Shivappa M, Chand PK, Murthy P, Benegal V: Baclofen in cannabis dependence syndrome. Biol Psychiatry 2010; 68:e9-e10.

156 Haney M, Hart CL, Vosburg SK, Comer SD, Reed SC, Cooper ZD, Foltin RW: Effects of baclofen and mirtazapine on a laboratory model of marijuana withdrawal and relapse. Psychopharmacology (Berl) 2010;211:233-244.

157 Brebner K, Ahn S, Phillips AG: Attenuation of d-amphetamine self-administration by baclofen in the rat: behavioral and neurochemical correlates. Psychopharmacology (Berl) 2005;177:409-417.

158 Li SM, Yin LL, Ren YH, Pan LS, Zheng JW: GABA(B) receptor agonist baclofen attenuates the development and expression of $\mathrm{d}$ methamphetamine-induced place preference in rats. Life Sci 2001;70:349-356.

159 Ranaldi R, Poeggel K: Baclofen decreases methamphetamine self-administration in rats. Neuroreport 2002;13:1107-1110.

160 Muralidharan K, Rajkumar RP, Mulla U, Nayak RB, Benegal V: Baclofen in the management of inhalant withdrawal: a case series. Prim Care Companion J Clin Psychiatry 2008;10:48-51.

161 Vlachou S, Markou A: GABAB receptors in reward processes. Adv Pharmacol 2010;58: 315-371.

162 Colombo G, Addolorato G, Agabio R, Carai MA, Pibiri F, Serra S, Vacca G, Gessa GL: Role of GABA(B) receptor in alcohol dependence: reducing effect of baclofen on alcohol intake and alcohol motivational properties in rats and amelioration of alcohol withdrawal syndrome and alcohol craving in human alcoholics. Neurotox Res 2004;6:403-414.

163 Mordenti J: Man versus beast: pharmacokinetic scaling in mammals. J Pharm Sci 1986; 75:1028-1040.

164 Morris TH: Antibiotic therapeutics in laboratory animals. Lab Anim 1995;29:16-36.

165 Johnson BA: Medication treatment of different types of alcoholism. Am J Psychiatry 2010;167:630-639. 
166 Sturgess JE, George TP, Kennedy JL, Heinz A, Müller DJ: Pharmacogenetics of alcohol, nicotine and drug addiction treatments. Addict Biol 2011;16:357-376.

167 Heydtmann M: Baclofen effect related to liver damage. Alcohol Clin Exp Res 2011;35: 848.

168 Cartlidge NE, Hudgson P, Weightman D: A comparison of baclofen and diazepam in the treatment of spasticity. J Neurol Sci 1974;23: 17-24.

169 Roussan M, Terrence C, Fromm G: Baclofen versus diazepam for the treatment of spasticity and long-term follow-up of baclofen therapy. Pharmatherapeutica $1985 ; 4: 278$ 284.

170 Leggio L, Kenna GA, Swift RM: New developments for the pharmacological treatment of alcohol withdrawal syndrome. A focus on non-benzodiazepine GABAergic medications. Prog Neuropsychopharmacol Biol Psychiatry 2008;32:1106-1117.

-171 Macaigne G, Champagnon N, Harnois F, Cheiab S, Chayette C: Baclofen-induced acute hepatitis in alcohol-dependent patient. Clin Res Hepatol Gastroenterol 2011; 35:420-421.

172 Bombardier CH, Blake KD, Ehde DM, Gibbons LE, Moore D, Kraft GH: Alcohol and drug abuse among persons with multiple sclerosis. Mult Scler 2004;10:35-40.

173 Turner AP, Hawkins EJ, Haselkorn JK, Kivlahan DR: Alcohol misuse and multiple sclerosis. Arch Phys Med Rehabil 2009;90:842848.
174 Saddichha S, Jayaram N, Manjunatha N, Benegal V: Baclofen-induced morbiliform rashes: a case series. J Clin Pharmacol 2011; 51:1733-1734.

175 Rolland B, Bordet R, Cottencin O: Alcoholdependence: the current French craze for baclofen. Addiction 2012;107:848-849.

176 Gorsane MA, Kebir O, Hache G, Blecha L, Aubin HJ, Reynaud M, Benyamina A: Is baclofen a revolutionary medication in alcohol addiction management? Review and recent updates. Subst Abus 2012;33:336-349.

177 Enserink M: Addiction research. Anonymous alcoholic bankrolls trial of controversial therapy. Science 2011;332:653.

178 Filip M, Frankowska M, Przegaliński E: Effects of $\mathrm{GABA}_{B}$ receptor antagonist, agonists and allosteric positive modulator on the cocaine-induced self-administration and drug discrimination. Eur J Pharmacol 2007;574: 148-157.

179 Lhuillier L, Mombereau C, Cryan JF, Kaupmann K: $\mathrm{GABA}_{\mathrm{B}}$ receptor-positive modulation decreases selective, molecular and behavioral effects of cocaine. Neuropsychopharmacology 2007;32:388-398.
80 Paterson NE, Vlachou S, Guery S, Kaupmann K, Froestl W, Markou A: Positive modulation of $\mathrm{GABA}_{\mathrm{B}}$ receptors decreased nicotine self-administration and counteracted nicotine-induced enhancement of brain reward function in rats. J Pharmacol Exp Ther 2008; 326:306-314

181 Slattery DA, Markou A, Froestl W, Cryan JF: The $\mathrm{GABA}_{\mathrm{B}}$ receptor-positive modulator GS39783 and the GABAB receptor agonist baclofen attenuate the reward-facilitating effects of cocaine: intracranial self-stimulation studies in the rat. Neuropsychopharmacology 2005;30:2065-2072.

182 Smith MA, Yancey DL, Morgan D, Liu Y, Froestl W, Roberts DC: Effects of positive allosteric modulators of the $\mathrm{GABA}_{\mathrm{B}}$ receptor on cocaine self-administration in rats. Psychopharmacology (Berl) 2004;173:105-111.

183 Adams CL, Lawrence AJ: CGP7930: a positive allosteric modulator of the GABAB receptor. CNS Drug Rev 2007;13:308-316.

184 Agabio R, Maccioni P, Carai MAM, Gessa GL, Froestl W, Colombo G: The development of medication for alcohol-use disorders targeting the $\mathrm{GABA}_{\mathrm{B}}$ receptor system. Recent Pat CNS Drug Discov 2012;7:113-128.

185 Muzyk AJ, Rivelli SK, Gagliardi JP: Defining the role of baclofen for the treatment of alcohol dependence: a systematic review of the evidence. CNS Drugs 2012;26:69-78.

186 Mark TL, Kranzler HR, Song X, Bransberger $\mathrm{P}$, Poole VH, Crosse S: Physicians' opinions about medications to treat alcoholism. Addiction 2003;98:617-626.
Efficacy and Tolerability of Baclofen in Substance Use Disorders
Eur Addict Res 2013:19:325-345 